\title{
KAMISHAK FORMATION, PUALE BAY
}

\author{
by \\ Michel T. Whalen ${ }^{1}$ and Tyler W. Beatty ${ }^{1}$
}

\begin{abstract}
Four partial stratigraphic sections of the Kamishak Formation, near Puale Bay on the Alaska Peninsula, were examined for this study. Lithostratigraphic and petrographic analyses prompted subdivision of the Kamishak Formation into biostromal, nodular limestone and conglomerate, rhythmically bedded limestone, and siliceous limestone units. Sedimentary structures, biota, and ichnofabrics indicate that the biostromal unit was deposited in relatively shallow normal marine environments in a middle to inner carbonate ramp setting. The nodular limestone and conglomerate unit, with evidence of synsedimentary folding and mass movement processes, was deposited along a distally steepened slope of the carbonate ramp. The rhythmically bedded unit, with no evidence of wave or current structures, was deposited below storm wave base in a basinal setting. The siliceous limestone unit, with evidence of turbidite or tempestite deposition and abundant ichnofauna, indicates deposition above storm wave base on an outer carbonate ramp.

Organic geochemical data demonstrate that the Kamishak Formation contains good to very good source rocks with best source potential within the siliceous limestone and rhythmically bedded units. Kerogen types in the Kamishak Formation include Type I, II, and III with average values plotting as oil prone (Type II). Rock-Eval data indicate that Kamishak source rocks are near the boundary between immature and mature. The reservoir potential of the portion of the Kamishak Formation examined for this study is, in general, poor but some facies within the nodular limestone and conglomerate unit display macro- and micro-scale porosity. Secondary fracture porosity and dolomitization in the biostromal unit may also provide some reservoir potential.
\end{abstract}

\section{INTRODUCTION}

The Kamishak Formation, exposed near Puale Bay (figs. 1-3), is a relatively complete but slightly deformed Triassic and Jurassic succession in south-central Alaska (Imlay and Detterman, 1977; Detterman and Reed, 1980; Wang and others, 1988; Detterman and others, 1996). The Upper Triassic to Lower Jurassic Kamishak Formation comprises about $800 \mathrm{~m}$ of marine, dominantly carbonate, rocks that are interbedded with basaltic volcanic and volcaniclastic rocks in the upper portion of the section (Wang and others, 1988; Detterman and others, 1996).

The purpose of this study is to evaluate the Kamishak Formation in the Puale Bay area in light of other recent work (Detterman and others, 1996; Sralla and Blodgett, 2007; Blodgett and Sralla, 2008) and provide insight into the lithofacies, depositional environment, and source rock and reservoir potential of the unit.

\section{STRATIGRAPHIC CONTEXT}

Contact relations of the Upper Triassic Kamishak Formation at Puale Bay are not well understood. Wang and others (1988) considered the base of the Triassic section to be truncated by faulting and that was confirmed, at least on a local basis, during this study. Volcaniclastic conglomerates and breccias exposed just to the west of Cape Kekurnoi (07MW001) have been variably inter-

preted and this issue will be addressed further below.

Wang and others (1988) evaluated the Upper Triassic portion of the section near Puale Bay that records the geological evolution of a volcanic island arc. Imlay (1981) documented the presence of Lower Jurassic Hettangian age rocks and Newton (1989) contended that the Triassic-Jurassic (T-J) boundary section was complete. Pálfy and others (1999) studied the uppermost Triassic and lower Jurassic portion of the section and demonstrated that Hettangian rocks were present but that the $\mathrm{T}-\mathrm{J}$ boundary was missing due to minor faulting. The upper contact of the Kamishak Formation is gradational with the overlying Talkeetna or Bidarka Formation and is associated with a decrease in carbonate content at the expense of fine-grained siliciclastic material (Detterman and others, 1996; Pálfy and others, 1999)

\section{METHODS}

Stratigraphic sections within the Kamishak Formation were measured in the field with a Jacob's staff and compass. Lithofacies were identified and logged at sub-meter resolution noting lithology, color, bedding character, sedimentary structures, trace fossils, and body fossils. At major changes in lithofacies, samples were collected for thin section, Total Organic Carbon (TOC), Rock-Eval pyrolysis, and/or reservoir seal analyses.

${ }^{1}$ Department of Geology and Geophysics, Universityof Alaska, P.O. Box 755780 Fairbanks, Alaska 99775-5780 


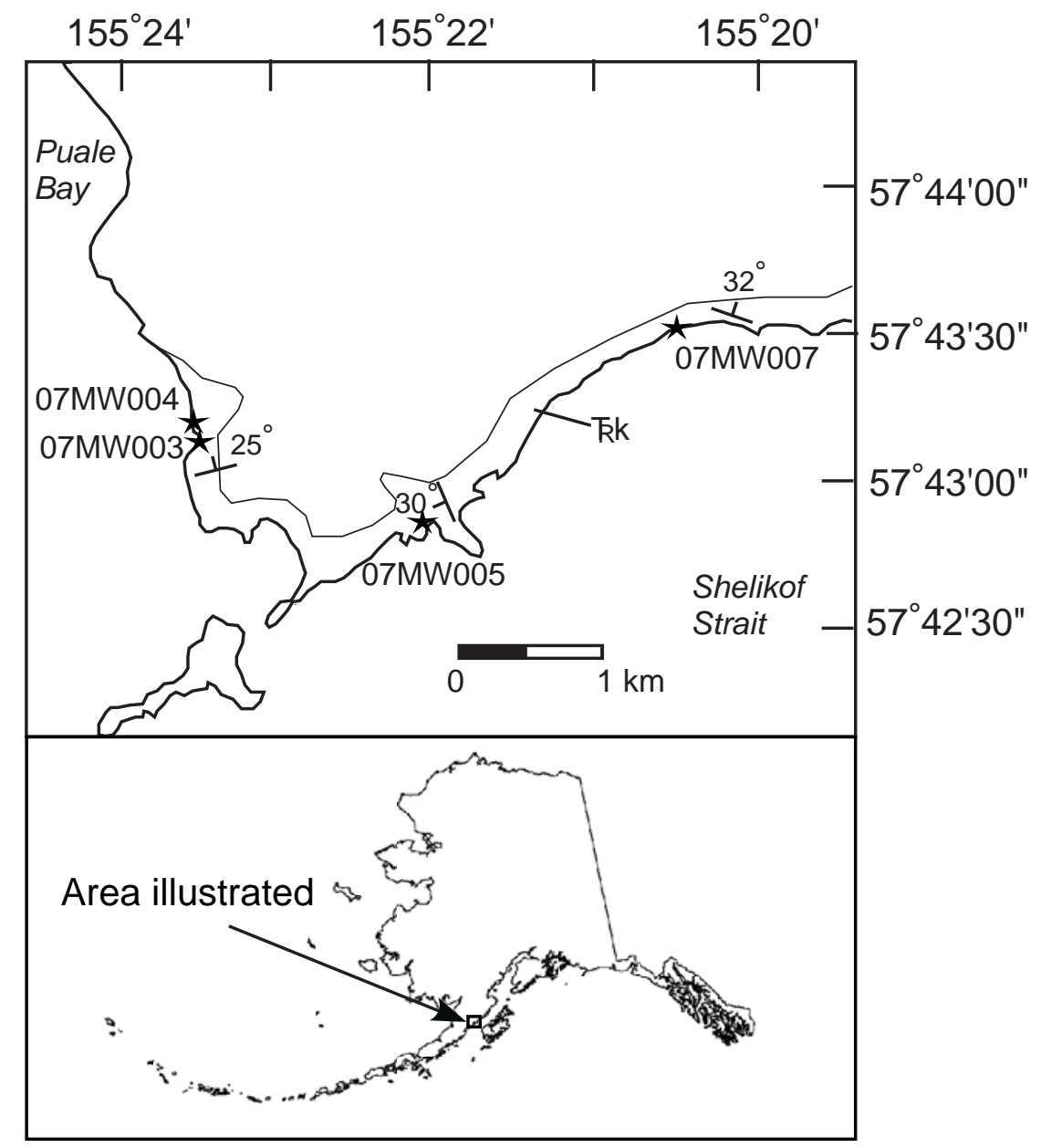

Figure 1. Location map. Map of Cape Kekurnoi located to the east of Puale Bay, illustrating the distribution and attitude of the Kamishak Formation (TR $k$ ) and the locations (labeled stars) of measured stratigraphic sections (modified from Detterman and others, 1996; Wilson, and others, 1999; Decker, this volume).

Samples for TOC and Rock-Eval pyrolysis were processed by Baseline Resolution, Inc. (143 Vision Park Blvd., Shenandoah, Texas 77384) while those for seal analysis were evaluated by George Bolger, PetroTech Associates (11767 Katy Freeway, Suite 320, Houston, Texas 77079). Thin sections were stained for calcite with Alizarin Red-S and vacuum impregnated with blue epoxy to help evaluate porosity. Thin sections were examined with a Nikon Optiphot petrographic microscope and digitally imaged using an Olympus Q-color camera and Q-capture software. Descriptions of carbonate-dominated lithofacies will follow the carbonate classification of Dunham (1962) as modified by Embry and Klovan (1972). Bedding thicknesses are classified as laminated ( $<1 \mathrm{~cm}$ thick), thin (1-10 cm thick), medium $(11-50 \mathrm{~cm}$ thick), and thick bedded (51-100 cm thick), or massive $(>100 \mathrm{~cm}$ thick).

\section{MEASURED SECTIONS}

Four partial stratigraphic sections, totaling $156 \mathrm{~m}$ of section, within the Upper Triassic part of the Kamishak Formation were measured during this study and 41 samples were collected within the unit (table 1, fig. 1). Blodgett (this report) provides biostratigraphic and paleontologic information concerning these sections. Section 07MW005 (fig. 4) is the lowest within the stratigraphic succession beginning approximately $35 \mathrm{~m}$ above the base of the exposed section, which is truncated by a fault (Wang and others, 1988). This section begins within what was identified as a coral biomicrite unit and continues up through a carbonate conglomerate (unit 1 of Detterman and others, 1996) and the lowermost bedded chert facies of Wang and others (1988; lower part, unit 2 of Detterman and others, 1996). Section 07MW007 (fig. 5) is in part laterally equivalent with section 07MW005. It begins within lateral equivalents of the coral biomicrite 


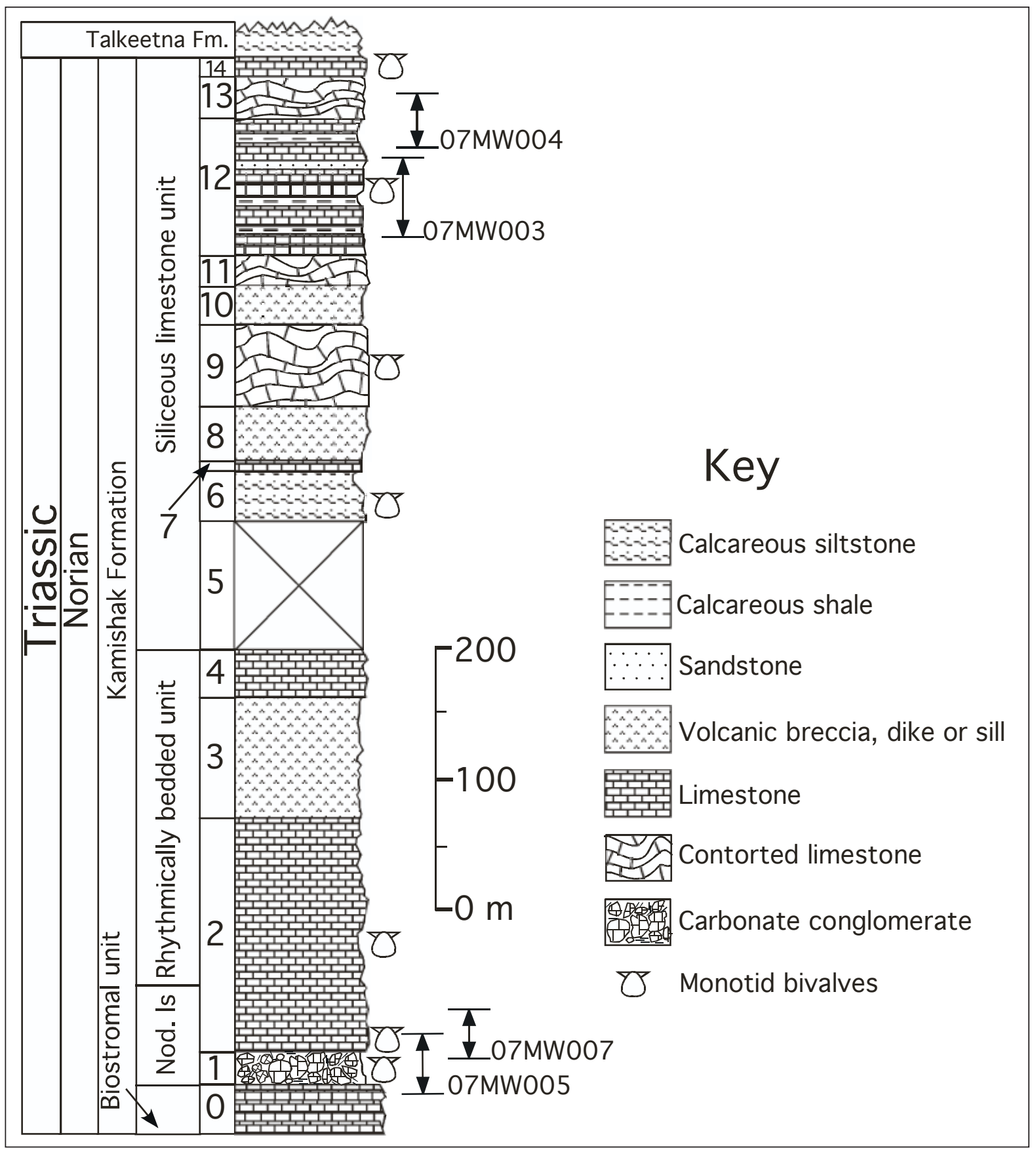

Figure 2. Composite stratigraphic section of the Kamishak Formation near Puale Bay (after Wang and others, 1988; Detterman and others, 1996; this study). Diagram illustrates the age, lithologies, units defined in this study, and thickness in meters (m) of the Kamishak Formation near Puale Bay. Numbers in the column to the left of the lithologic column indicate units of Detterman and others (1996). The stratigraphic position of measured sections from this study (figs. 4-7) is indicated to the right of the lithologic column. Nod. Is = Nodular limestone and conglomerate unit. 


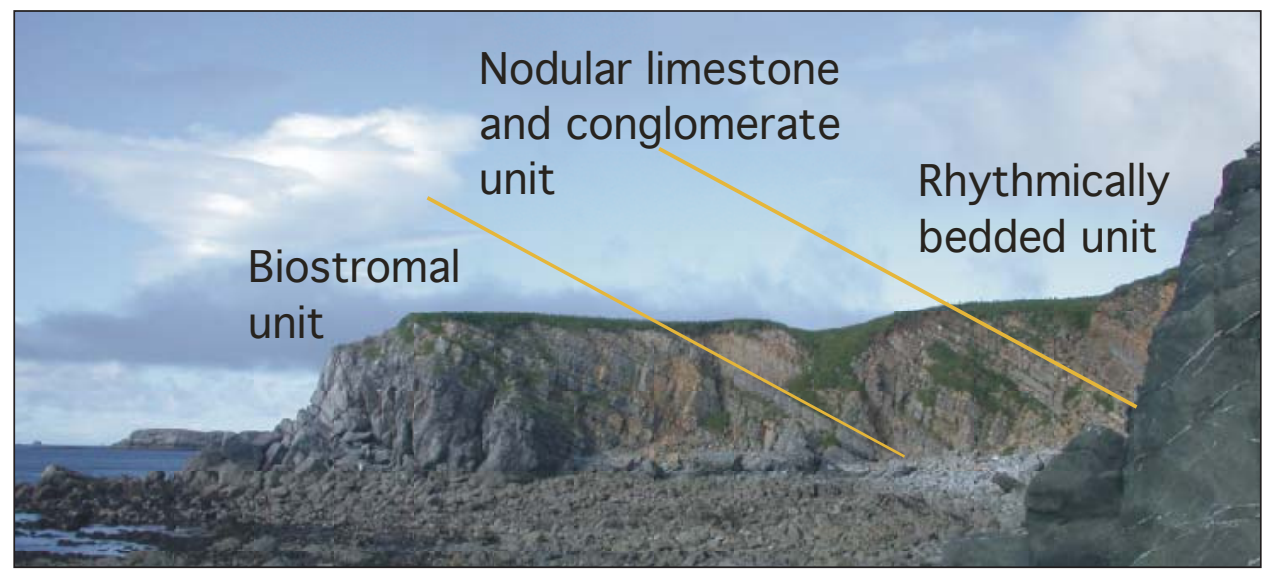

Figure 3. Outcrop photograph of the lower portion of the Kamishak Formation exposed near Puale Bay, illustrating the biostromal, nodular limestone and conglomerate, and lower portion of the rhythmically bedded unit.

Table 1. Measured stratigraphic sections in the Kamishak Formation. Section number, latitude and longitude of the base of the section, general attitude of the rocks, and thickness of each measured section are outlined.

\begin{tabular}{cccc} 
Measured Section & Latitude/Longitude & Strike/Dip & Thickness \\
07MW003 & N57.71887, W155.38973 & N74, $25^{\circ} \mathrm{NW}$ & $60 \mathrm{~m}$ \\
07MW004 & N57.72031, W155.38978 & N67, $8^{\circ} \mathrm{NW}$ & $13 \mathrm{~m}$ \\
$07 \mathrm{MW005}$ & $\mathrm{N} 57.71372, \mathrm{~W} 155.36167$ & $\mathrm{~N} 156^{\circ}, 30^{\circ} \mathrm{SW}$ & $52 \mathrm{~m}$ \\
$07 \mathrm{MW007}$ & $\mathrm{N} 57.72525, \mathrm{~W} 155.34082$ & $\mathrm{~N} 110^{\circ}, 32^{\circ} \mathrm{NE}$ & $31 \mathrm{~m}$ \\
\hline
\end{tabular}

and continues through the carbonate conglomerate facies (unit 1 of Detterman and others, 1996) and lower bedded chert unit of Wang and others (1988; lower part of unit 2 of Detterman and others, 1996). Sections 07MW003 (fig. 6) and 004 (fig. 7) are in the upper part of the Upper Triassic portion of the section and would be entirely within the upper part of Wang and others' (1988) bedded chert facies (units 12-13 of Detterman and others, 1996).

Reference to the facies described by Wang and others (1988) and Detterman and others (1996) are presented here as a guide to readers wishing to place this report in context with previously published work. A somewhat different facies classification and interpretation of the depositional setting of these Upper Triassic rocks resulted from field analysis, hand specimen examination, and thin section petrography conducted during this study.

\section{UNITS AND FACIES}

Lithostratigraphic, facies, and microfacies analyses provide evidence of four different lithostratigraphic units, each of which contains several individual facies.
Lithostratigraphic units described here include: (1) biostromal, (2) nodular limestone and conglomerate, (3) rhythmically bedded, and (4) siliceous limestone units. Following the unit designations will be a description of the ichnology of the siliceous limestone unit, which contributes to depositional and paleoenvironmental interpretations. Interpretations of depositional environment and comparison with earlier interpretations follow in the subsequent section.

\section{BIOSTROMAL UNIT}

This unit is equivalent to the coral biomicrite of Wang and others (1988) who documented the unit to be about $45 \mathrm{~m}$ thick. Approximately $10 \mathrm{~m}$ of the upper portion of the unit were examined for this study at measured section 07MW005 (fig. 4). The unit consists of medium-bedded to massive carbonate rocks that weather light gray and medium brown and are mottled medium brown and white on fresh surfaces (figs. 8,9). Thinner lateral equivalents crop out at section 07MW007 (fig. 5) but are interbedded with nodular limestones similar to rocks that overlie the biostromal unit at section 07MW005. 

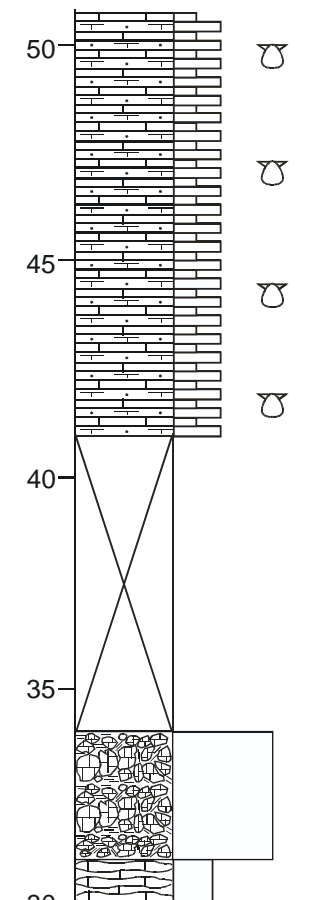

Key
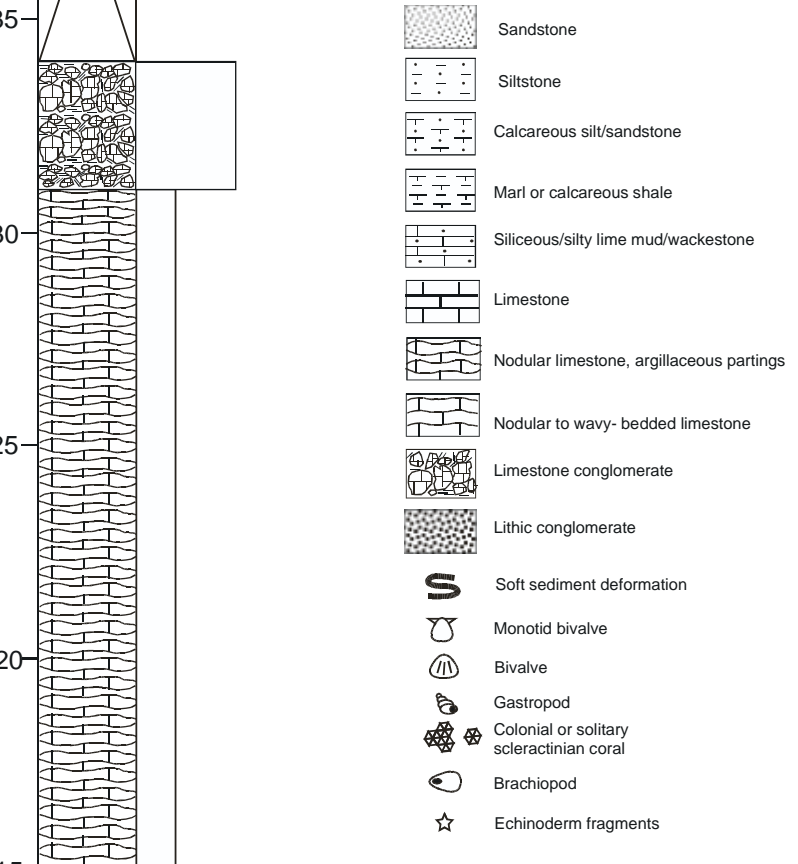

Echinoderm fragments

Figure 4. Measured stratigraphic section 07MW005 that exposes the upper biostromal unit, nodular limestone and conglomerate, and lower rhythmically bedded unit. Diagram illustrates lithologies, units defined in this study, thickness in meters (m), average grain size ( $C=$ clay, $S t=$ silt, $S d=$ sand, $G=$ gravel, $B=$ boulder), and common body fossils. 


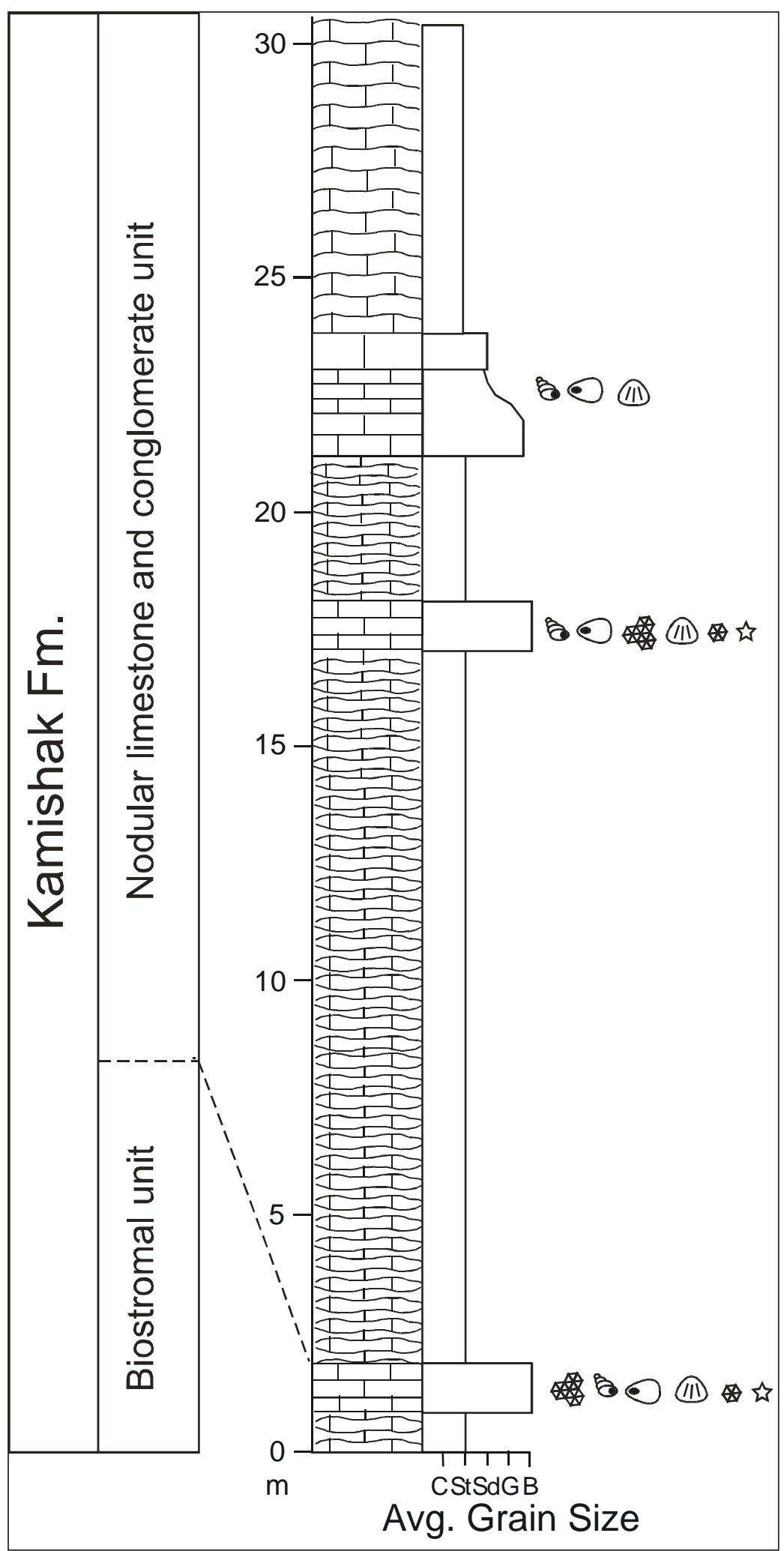

Figure 5. Measured stratigraphic section 07MW007 records the upper portion of the biostromal unit and the lower part of the nodular limestone and conglomerate unit. Diagram illustrates lithologies, units defined in this study, thickness in meters $(m)$, average grain size $(C=$ clay, $S t=$ silt, $S d=$ sand, $G=$ gravel, $B=$ boulder $)$, and common body fossils. See figure 4 for key to lithologies and other symbols. 


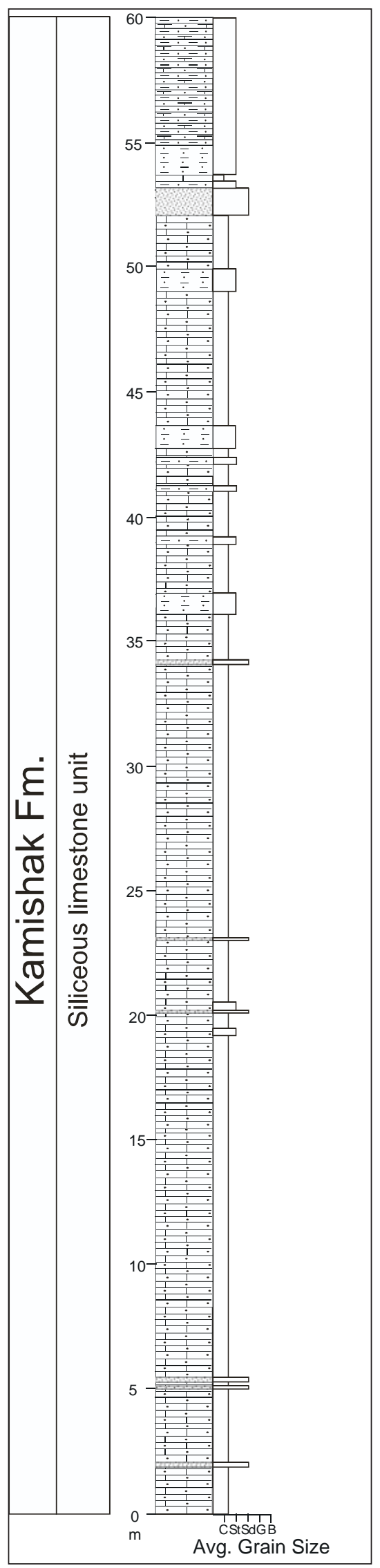

Figure 6. Measured stratigraphic section 07MW003 exposes part of the siliceous limestone unit. Diagram illustrates lithologies, units defined in this study, thickness in meters $(m)$, average grain size ( $C=$ clay, $S t$ $=$ silt, $S d=$ sand, $G=$ gravel, $B=$ boulder), and common body fossils. See figure 4 for key to lithologies and other symbols.

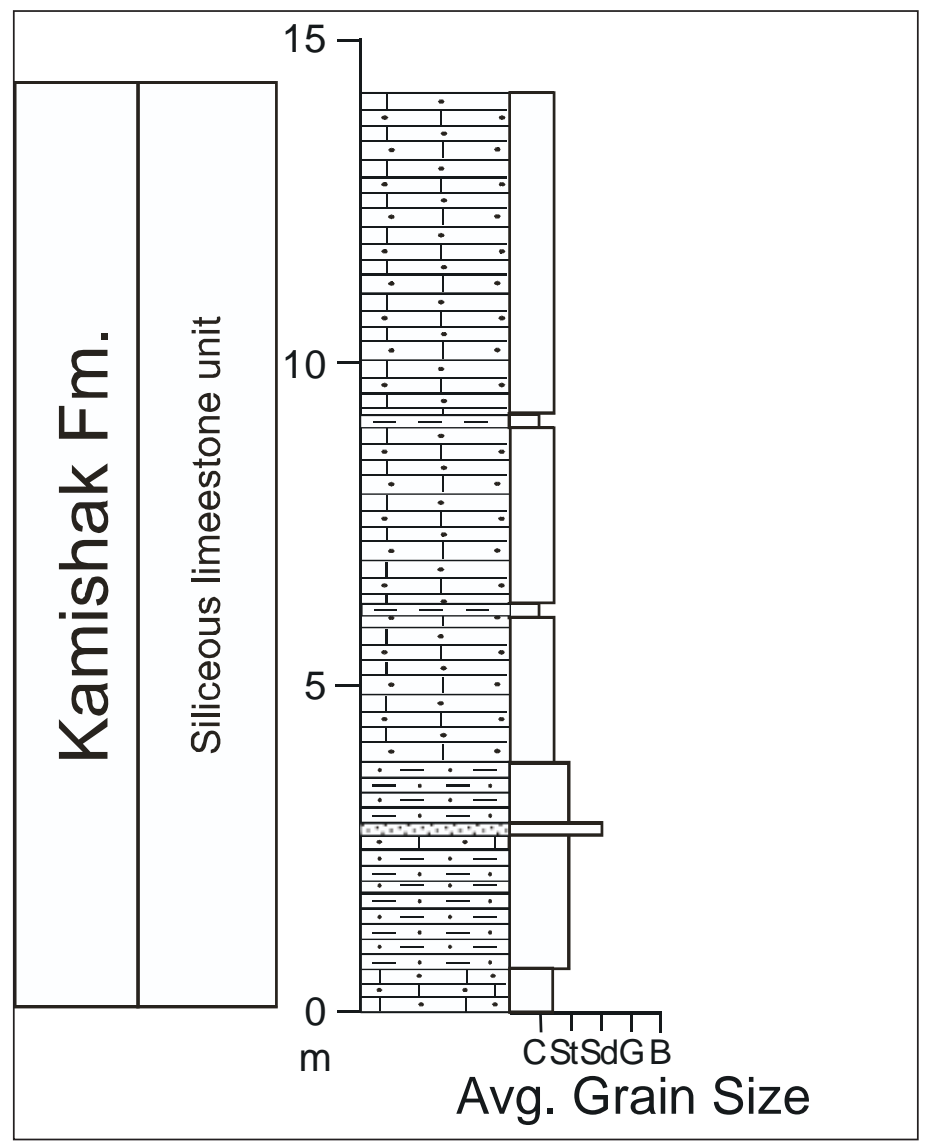

Figure 7. Measured stratigraphic section 07MW004 records part of the siliceous limestone unit. Diagram illustrates lithologies, units defined in this study, thickness in meters $(m)$, average grain size $(C=$ clay, $S t=$ silt, $S d=$ sand, $G=$ gravel, $B=$ boulder), and common body fossils. See figure 4 for key to lithologies and other symbols. 

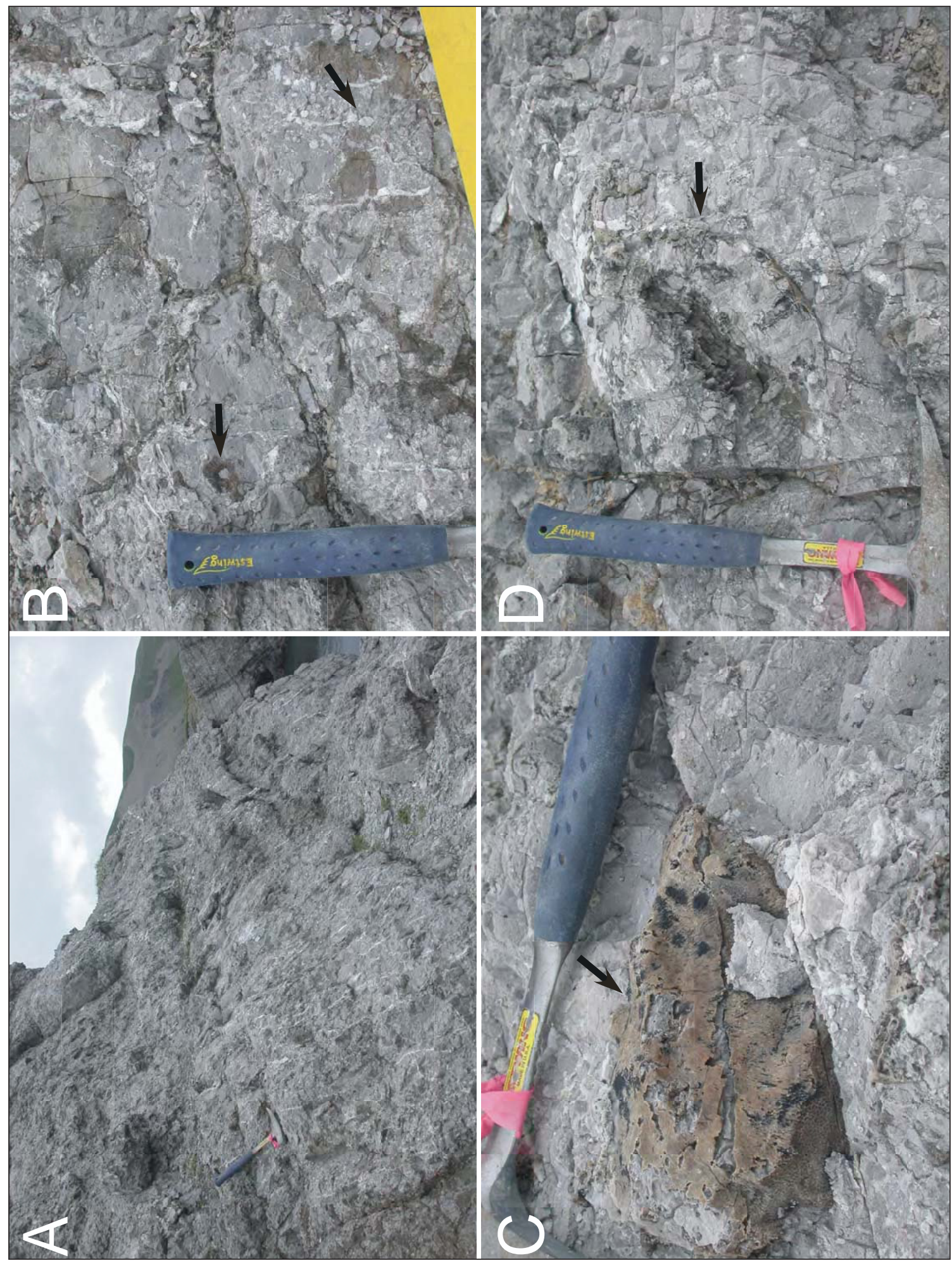

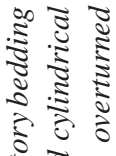

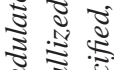

赵

吾

ปे $\frac{1}{2}$

$\delta \equiv$

ปี

:

웅

ร ठิ

ปิ โ.

‥ ‥

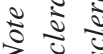

$\stackrel{5}{\sigma}$

ฐ

हิ ปั

ริ ฮ

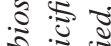

苂

范。

के चे

ㅎํㄴ

ป ई है

का

한

๓

षี รี

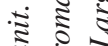

施ن

हี :

ड़े

능

₹

ऽ

के के

ธิ ป

¿ $\frac{0}{0}$

ล. ڤ

ปั

ปัฐ

$\infty$ है

ڤ

క 
The biostromal unit contains a mixture of bioclastic wackestone, packstone, floatstone, and rudstone with abundant colonial scleractinian corals, spongiomorphs, and terebratulid brachiopods (figs. 8-10) (Wang and others, 1988; this study) and common gastropods, bivalves, echinoderm fragments (echinoid spines and crinoid ossicles), and solitary scleractinian corals. Most bioclasts appear to be transported including colonial coral heads, more than $20 \mathrm{~cm}$ in diameter, some of which are completely overturned (fig. 8).

The facies within this unit are highly fractured, partially dolomitized, and partly silicified. Within the portion of the biostromal unit examined for this study, 50-500 $\mu \mathrm{m}$ planar euhedral to subhedral dolomite rhombs are fabric destructive and replace both grains and lime mud matrix. Based on visual estimates, dolomite does not make up more than 25 percent of any of the facies examined and no increase in secondary porosity is associated with the dolomite. Petrographic observations indicate that the dolomite is cross cut by younger coarsely crystalline calcite fracture-filling cement. Microcrystalline quartz and spherulitic chalcedony replaces some grains, matrix, and late stage calcite cement.

\section{NODULAR LIMESTONE AND CON- GLOMERATE UNIT}

The nodular limestone and conglomerate unit overlies the biostromal unit and is dominantly composed of light gray-brown weathering bioclastic wackestone carbonate nodules that are medium gray on fresh surfaces (figs. 4, 5, 9 and 11). The lower $25 \mathrm{~m}$ was previously described as a depositional carbonate conglomerate (Wang and others, 1988). It is equivalent to unit 1 of Detterman and others (1996) but they provide no detailed lithologic description. The clasts in the conglomerate are very similar to nodules that make up the bulk of the overlying nodular limestone. The nodules are surrounded by dark gray (weathering and fresh) argillaceous to silty wackestone to packstone. The nodules contain a diverse fauna of corals, bivalves, ammonoids, nautiloids, and gastropods (figs. 9, 10) (Wang and others, 1988; this study). The base of this unit is quite complex and comprises several facies, one of which is similar to Wang and others' (1988) carbonate conglomerate. This conglomerate contains cobble-size clasts that are identical to the nodules described above and the matrix of the conglomerate is similar to the material interbedded with the nodules (figs. 9, 11). At the main exposure of these units, the conglomerate directly overlies the biostromal unit; however, a small exposure to the northeast (fig. 11), that is not visible from the main exposure, provides evidence of additional facies deposited above the biostromal unit and lends insight into the genesis of the conglomerate.
At this secondary exposure there is a thin package that includes the following facies (fig. 4): (1) $40 \mathrm{~cm}$ of light gray weathering (medium gray fresh) laminated to thin-bedded lime mudstone, (2) $45 \mathrm{~cm}$ of nodular limestone overlain by (3) $20 \mathrm{~cm}$ of light gray-brown weathering, reverse graded rudstone with sand to pebble-size, greenish volcanic clasts and medium gray weathering carbonate lithoclasts in a packstone matrix (fig. 11), (4) $60 \mathrm{~cm}$ of nodular limestone overlain by (5) $20 \mathrm{~cm}$ of medium gray (weathering and fresh) finegrained, laminated packstone overlain by approximately (6) $2 \mathrm{~m}$ of nodular cobble conglomerate (fig. 11). The nodular limestone unit overlies this succession and becomes less conglomerate-like upsection. The laminated packstone and immediately overlying and underlying units illustrate the complex history of this interval. A small-scale asymmetric syncline/anticline pair, with an amplitude of about $1 \mathrm{~m}$, contorts these units (fig. 11). Primary bedding in the laminated packstone unit is preserved within the limbs of the fold but the texture of the rock was largely destroyed in the fold axes where the laminated packstone, rudstone, and nodular cobble conglomerate units are all deformed (fig. 11). The overlying nodular cobble conglomerate (\#6 above) also contains clasts of the packstone and rudstone units.

At locality 07MW007 this deformed unit is not present above the biostromal unit. Instead, there are thick beds of nodular limestone and lithoclastic/bioclastic floatstone and rudstone interbedded with tabular beds of bioclastic wackestone and packstone similar to the underlying biostromal unit (figs. 5, 9).

\section{RHYTHMICALLY BEDDED UNIT}

This unit consists of rhythmically interbedded brownish weathering argillaceous mud/wackestone or calcareous shale and light gray weathering silty mud/ wackestone. A thick package of volcaniclastic rocks is interbedded with this unit (fig. 2). The rhythmically bedded unit is equivalent to the lower portion of Wang and others' (1988) bedded chert unit and the upper portion of unit 2 and units 3 (volcaniclastic) and 4 of Detterman and others (1996; fig. 2). The argillaceous or shaly lithofacies are usually laminated, thin bedded, and fissile. The silty mud/wackestone lithofacies is more resistant and thin to medium bedded. Both are medium to dark gray on fresh surfaces and contain abundant well-preserved Monotid bivalves and rare gastropods. The unit overlies the nodular limestone and conglomerate unit (figs. 4, 5, and 12). The contact between the two is separated by a $7 \mathrm{~m}$ covered interval in measured section 07MW005 (fig. 4). The contact is exposed at section 07MW007 that records a gradational change from nodular limestone to the rhythmically bedded unit (fig. 12).

At two localities just to the west of Cape Kekurnoi the rhythmically bedded unit is associated with greenish 


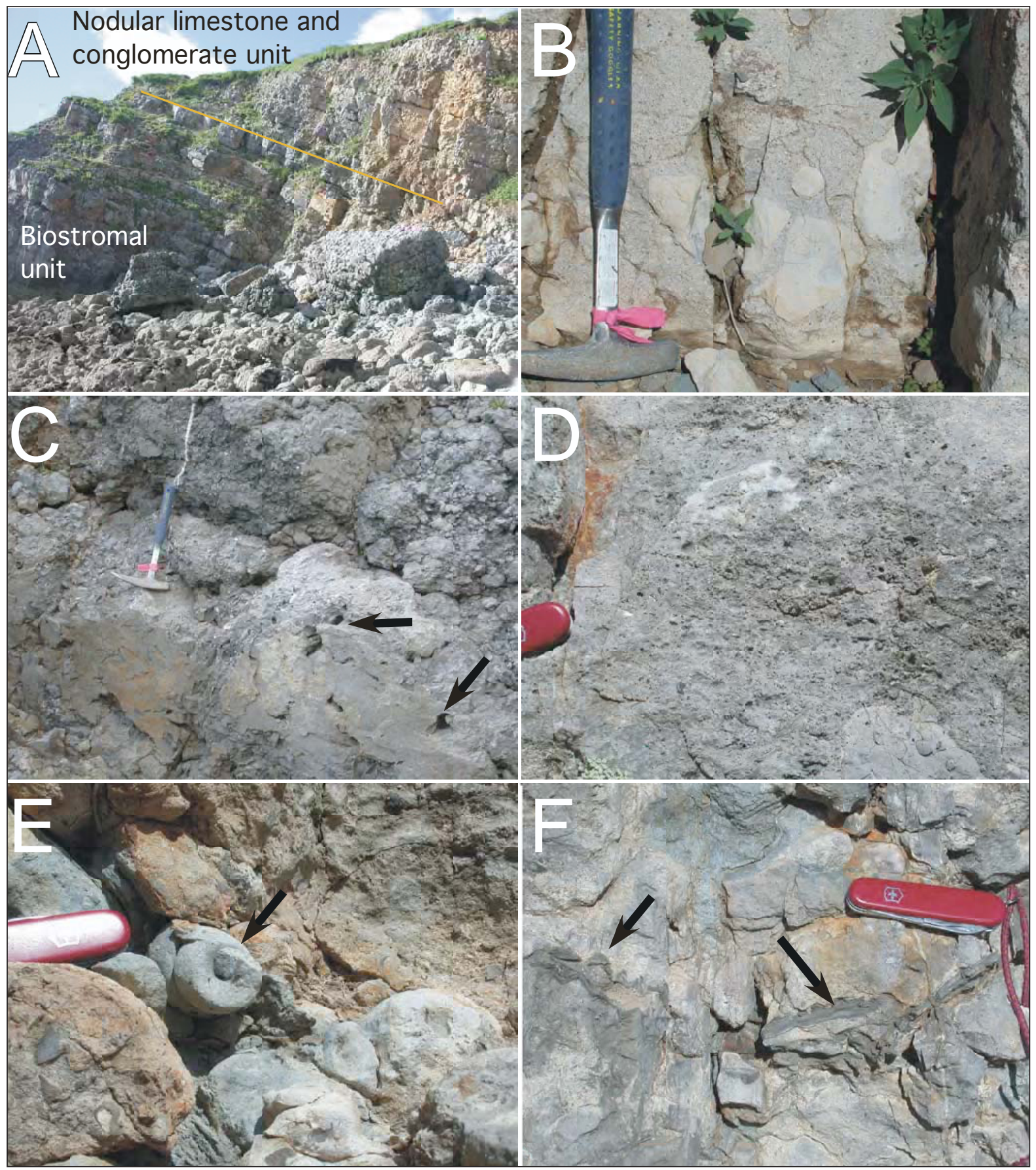

Figure 9. Biostromal and nodular limestone and conglomerate units. A. Outcrop photograph at locality 07 MW007 illustrating the contact between the biostromal and nodular limestone and conglomerate units. B. Floatstone in the lower nodular limestone and conglomerate unit with cobble-size subrounded carbonate lithoclasts within a bioclastic-lithoclastic matrix. C. Lower portion of the nodular limestone and conglomerate unit illustrating nodular texture and large-scale dissolution vugs (arrows). D. Millimeter-scale vugs within a floatstone in the lower nodular limestone and conglomerate unit. E. Large, high-spired gastropod steinkern (arrow) and rounded carbonate lithoclasts in a rudstone in the lower nodular limestone and conglomerate unit. F. Carbonate lithoclasts and thick shelled oysters (arrows) in a rudstone, nodular limestone and conglomerate unit. 

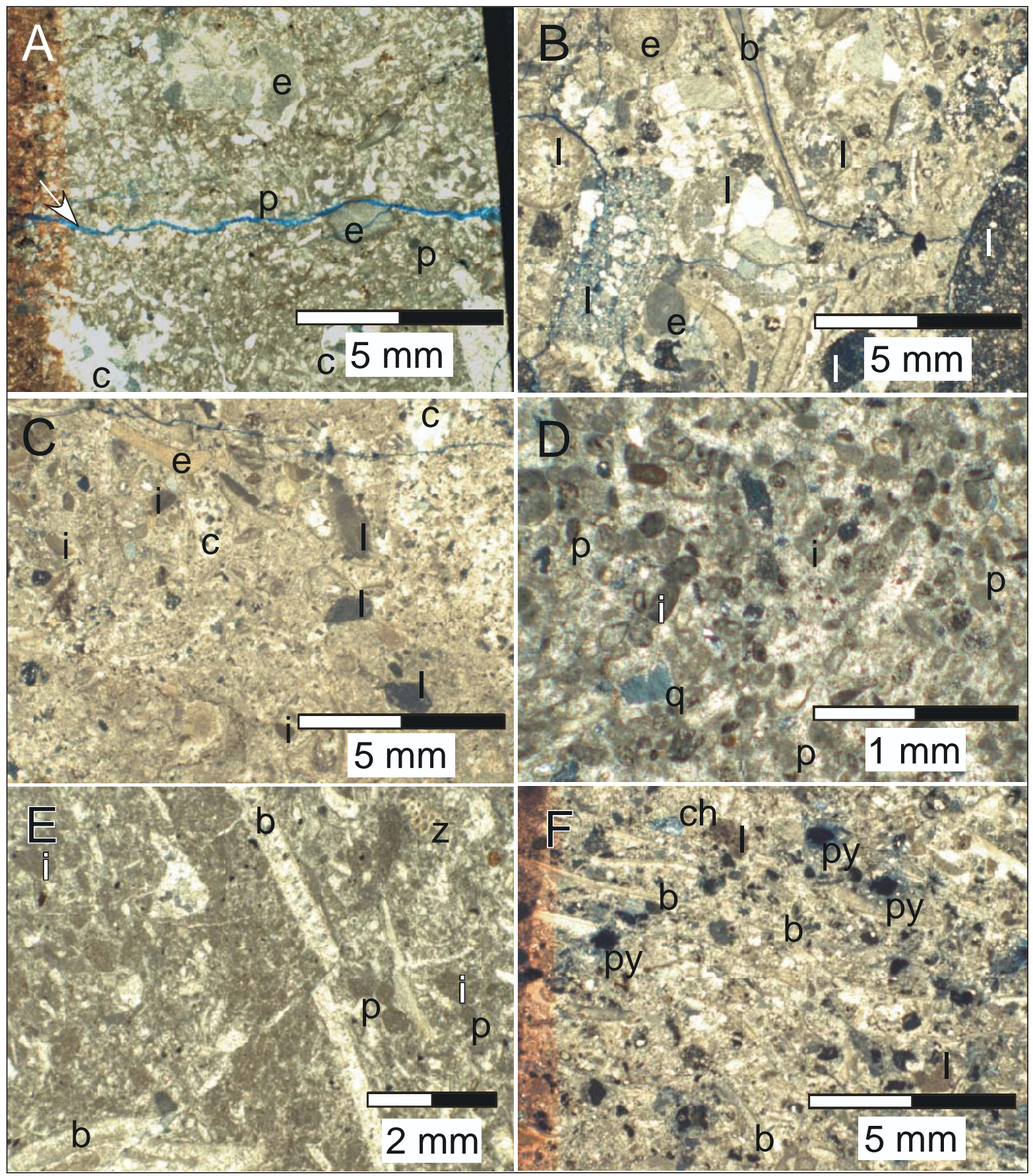

Figure 10. Photomicrographs of the Kamishak Formation biostromal and nodular limestone and conglomerate units. All photomicrographs taken under crossed polars. A. Bioclastic packstone from the upper part of the biostromal in measured section 07MW005 unit with echinoderm fragments (e), fine-grained unidentifiable skeletal grains, local peloids (p), and interstitial lime mud. Primary pores are filled with blocky calcite cement (c) and the only remaining porosity is within fractures (arrow) now filled with blue epoxy. B. Lithoclastic-bioclastic rudstone from the lower portion of the deformed interval near the base of the nodular limestone and conglomerate unit in measured section 07MW005. Note the abundant lithoclasts (l), thin-shelled bivalves (b), and echinoderm grains (e). Lithoclasts vary in composition and include volcaniclastic sandstone, carbonate mud-wackestone, and silty lime mud-wackestone. C. Bioclastic-lithoclastic rudstone from the lower part of the nodular limestone and conglomerate unit in measured section 07MW007. Note the abundant skeletal grains, including bivalve (b), echinoderm (e), an unidentifiable fine-grained component, lithoclasts (l), and intraclasts (i). Lithoclasts are dominated by subangular to subrounded lime mudstone clasts. Minor primary porosity was filled with calcite cement (c). D. Peloidal-intraclastic pack-grainstone in the lower nodular limestone unit in measured section 07MW007. Peloids (p) and intraclasts (i) dominate this facies that locally contains lime mud. E. Bioclastic-intraclastic packstone from the middle nodular limestone and conglomerate unit. Bivalve fragments (b), intraclasts (i), peloids (p), and bryozoan (z) fragments are illustrated. F. Bioclastic-lithoclastic rudstone in the upper nodular limestone and conglomerate unit in measured section 07MW007. Not the thin-shelled bivalves (b), chert lithoclasts (ch), and pyrite (py). Also note the minor dissolution-related porosity (blue epoxy) around corroded pyrite crystals. 

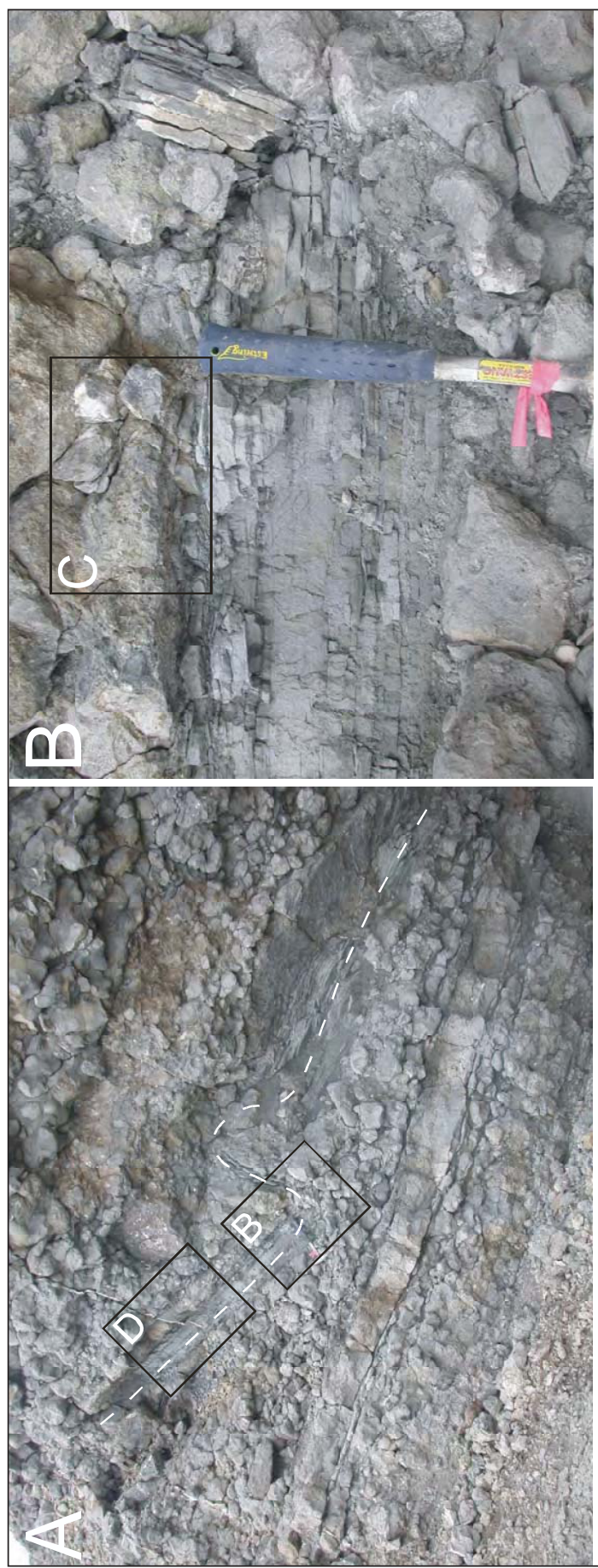
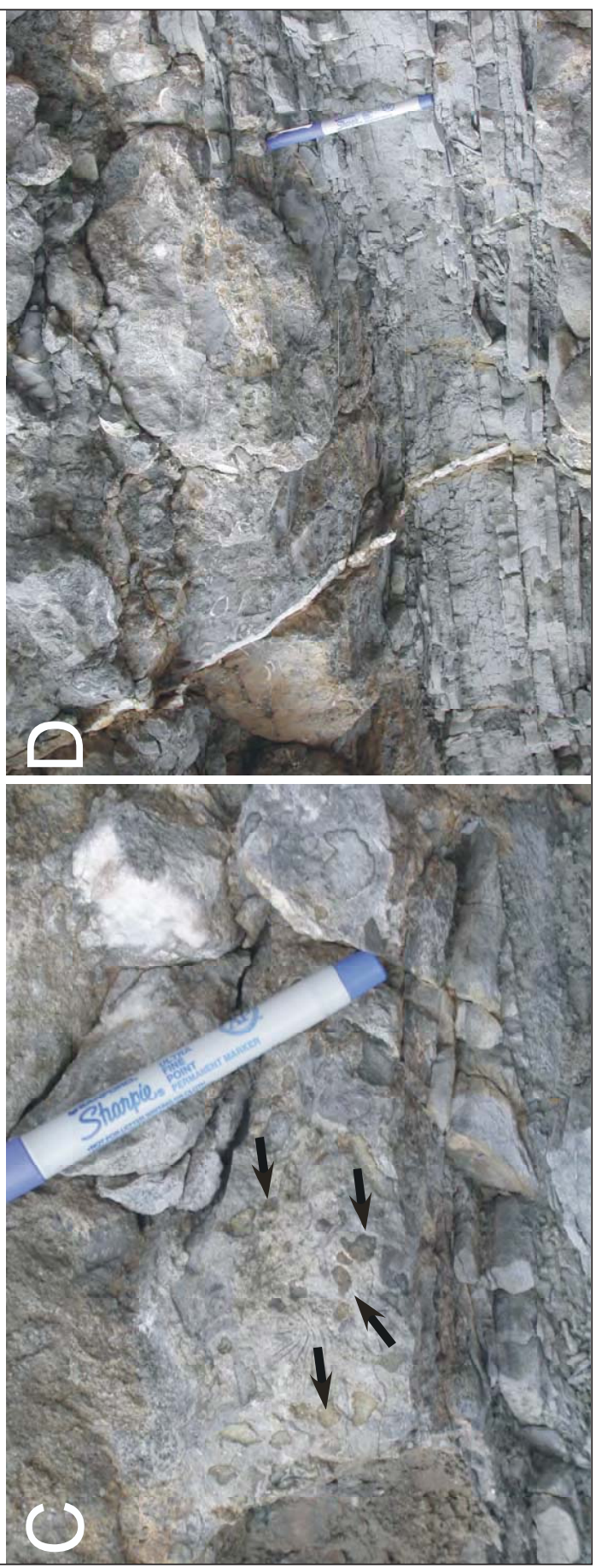

ซี ฐ ฐ

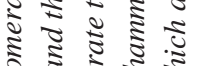

כ)

ठ 屯ै

ปี

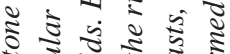

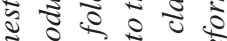

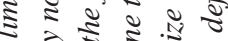

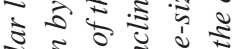

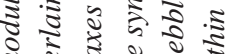

¿ वे है

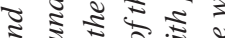

व $0.5 \%$

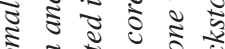

โ ฐ

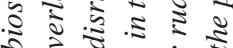

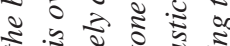

ป क

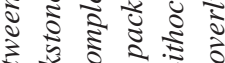

उै के

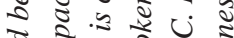

응 สำ

ว

छิ ปิ ปั)

ฐ $\vdots$ :

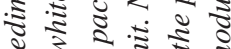

ป ฐ

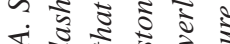

ते वे

ปี

- ₹ิ วิ 0

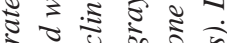

₹

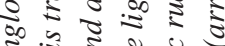

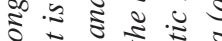

ป ฐ

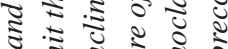

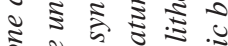

ะี ะี ฐี

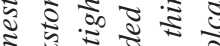

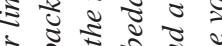

ప 2 ป

च छे छ

$=\approx$ s $\approx$ \&

ป :

क क

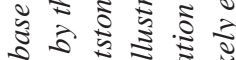

ะ

z

ซ

ธี

ริ ธิธี

$\Xi$ क

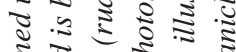

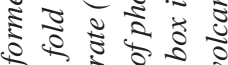

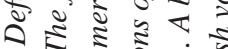

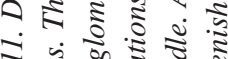

ๆ

空 


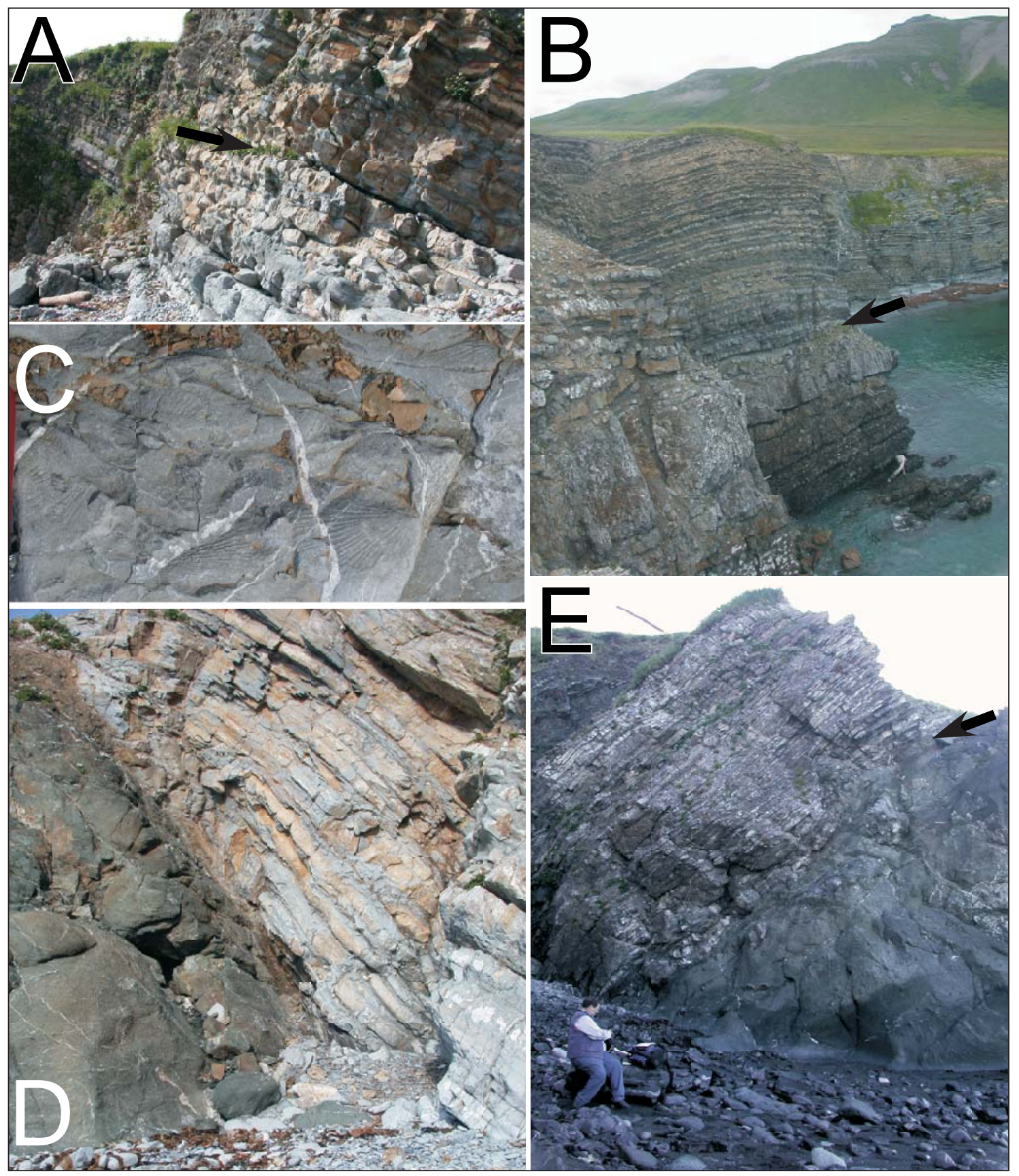

Figure 12. Outcrop photographs of the rhythmically bedded unit. A. Contact (arrow) between the nodular limestone and conglomerate unit and rhythmically bedded unit at locality 07MW007. Note the more nodular character of beds below the contact and more tabular bedding above. B. Contact (arrow) between the nodular limestone and conglomerate unit and the rhythmically bedded unit at the top of measured section 07MW005. The thick-bedded unit just beneath the arrow is the rudstone unit at $31 \mathrm{~m}$ in figure 4. C. Monotid bivalves in the rhythmically bedded unit in measured section 07MW005. D. Fault contact between the greenish volcanic breccias and rhythmically bedded unit at locality 07MW001. The high-angle contact is characterized by several centimeters of fault gouge. E. Rhythmically bedded unit in apparent depositional contact (arrow) with the volcanic breccia unit at locality 07MW001. The outcrop is just to the east of the fault contact illustrated in $D$. 
volcaniclastic breccias (Burk, 1965; Hill, 1979; Wang and others, 1988; Detterman and others, 1996; this study). Similar greenish volcaniclastic breccias are also interbedded with rocks herein categorized as the rhythmically bedded unit on the eastern side of the mouth to Puale Bay (Wang and others, 1988). These dark gray-green volcaniclastic lithologies contain breccia or conglomerate beds up to $50 \mathrm{~cm}$ thick and clasts up to 20 $\mathrm{cm}$ in diameter (Hill, 1979; this study). Sandy beds are 5-30 cm thick with local planar and trough cross-beds. At one locality near Cape Kekurnoi (07MW001) these breccias appear to be in depositional contact with the Kamishak Formation (fig. 12E). Overlying facies of the rhythmically bedded unit contain abundant monotid bivalves and are clearly Upper Triassic in age. However, in cliff exposures farther to the east there appears to be an angular unconformity between the breccias and the overlying Kamishak Formation (Hanson, 1957; Hill, 1979; Blodgett and Sralla, 2008). At a small outcrop (07MW006) farther to the west the greenish volcaniclastics are in fault contact with the overlying Monotis-bearing rhythmically bedded unit (fig. 12D).

\section{SILICEOUS LIMESTONE UNIT}

Dominantly 5-50-cm-thick beds of very hard, medium gray to yellowish weathering (dark gray fresh) planar to locally wavy bedded lime mud/wackestone and fine-grained bioclastic packstone, much of which is siliceous, comprise this unit (figs. 6,7 and 13). There are both a basalt flow and volcaniclastic rocks interbedded with this unit (fig. 2). The siliceous limestone is equivalent to the upper bedded chert unit of Wang and others (1988) and units 9 and 11-14 of Detterman and others (1996; fig. 2). While these rocks are relatively siliceous they are also very carbonate rich and do not display the typical vitreous luster or conchoidal fracture of bedded cherts. They were correctly identified as siliceous limestones by Newton (1983). Siliceous components include radiolaria, sponge spicules, and chalcedony and microcrystalline quartz cement and replacement material (fig. 14). Foraminifera, echinoderm fragments, and calcitized radiolaria are the most common carbonate clasts (fig. 14). The rocks of this unit are commonly fractured and locally brecciated. Calcite fills most fractures and cements some breccias.

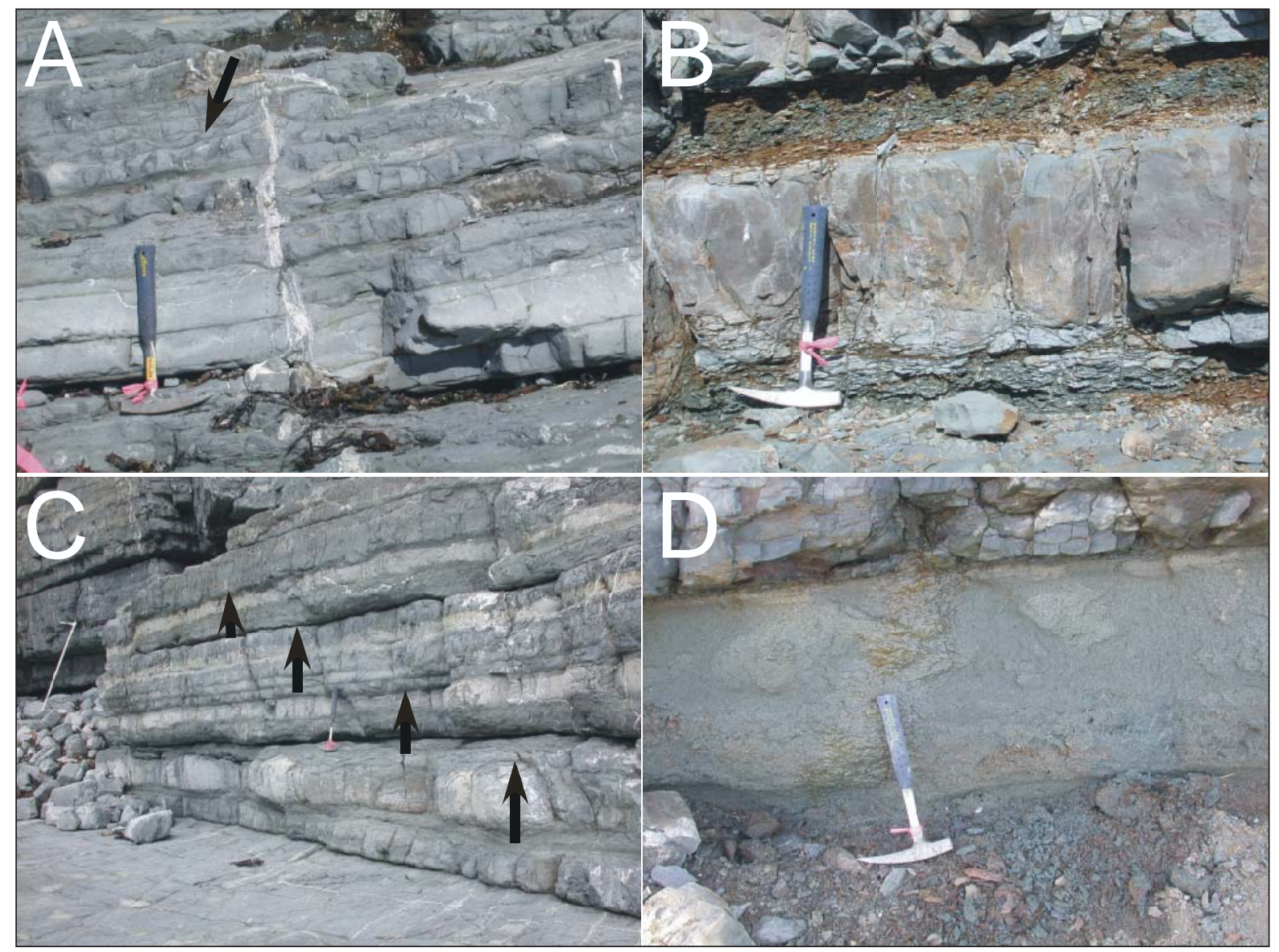

Figure 13. Outcrop photographs of the siliceous limestone unit. A. Thin to medium planar to wavy (arrow) bedded siliceous limestone in measured section 07MW003. B. Interbedded calcareous shale and medium-bedded siliceous limestone in measured section 07MW003. C. Several cycles (arrows) thicken and coarsen upward from mudstone to packstone in measured section 07MW003. D. Medium thick greenish volcaniclastic sandstone bed in measured section 07MW003. 


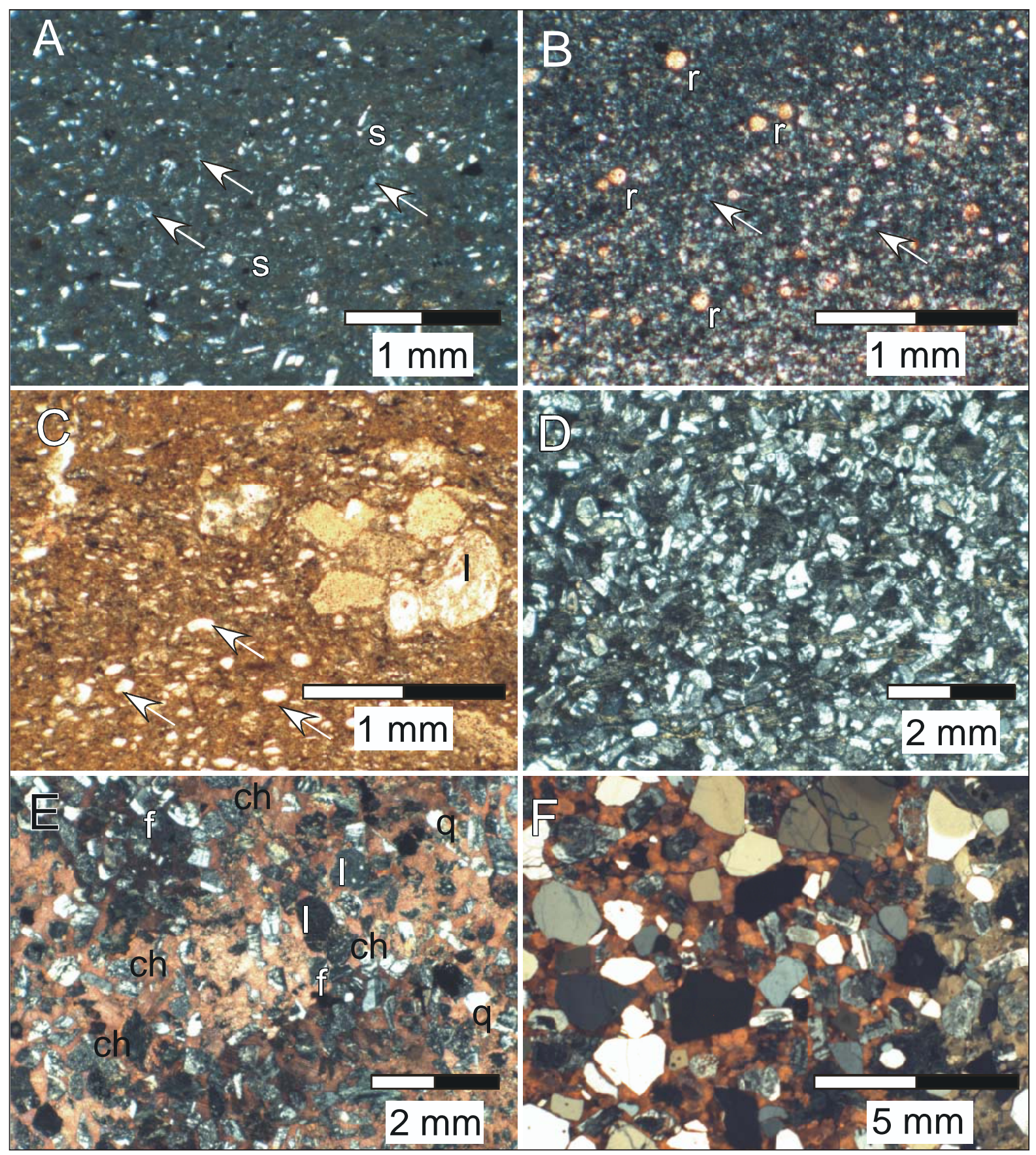

Figure 14. Photomicrographs of the siliceous lime mudstone unit and interbedded volcaniclastic and sandstone facies, Kamishak Formation, measured section 07MW003. All photomicrographs taken under crossed polars except where noted. A. Siliceous lime mudstone with quartz and feldspar silt, siliceous spicules (s), and microcrystalline quartz cement (arrows). B. Siliceous wackestone with calcitized radiolaria ( $r$ ) that are stained red with Alizarin Red-S, fine-grained quartz, and microcrystalline quartz cement (arrows). C. Wackestone with volcaniclastic lithics, individual mineral grains, and glass shards (arrows). Plane-polarized light. D. Volcaniclastic arenite with subangular to subrounded partially altered plagioclase and orthoclase feldspars, quartz, lithics, and minor clay matrix. E. Calcite-cemented quartzo-feldspathic, lithic arenite. Major framework grains include subangular to rounded plagioclase feldspar, quartz, and chert (ch) and lime mud-wackestone lithics (I). Calcite cement is stained red with Alizarin Red-S. F. Calcite-cemented quartz arenite with subangular to rounded, dominantly monocrystalline quartz and minor quantities of plagioclase feldspar and chert lithics. Interstitial calcite cement stained with Alizarin Red-S. 
Beds within this unit commonly thicken and coarsen upward in packages 10 to $50 \mathrm{~cm}$ thick. Planar-bedded units are locally laminated, sharp-based with scours, and grade upward from packstone to mudstone. Some of the wavy-bedded units appear to display hummocky cross stratification with low-angle laminated wackestone that downcuts into underlying mudstone. Most facies within the unit are highly bioturbated with abundant Rosellia rotatus, Cylindrichnus isp., and Thallasinoides isp., common Chondrites isp., and a variety of other traces described in more detail in the next section (fig. 15).

The above lithology is intercalated with several other medium to dark gray-brown weathering, thin-bedded facies including argillaceous or silty mud/wackestone and calcareous siltstone and gray-green weathering sandstone (figs. 13, 14). These interbedded facies are usually recessive. The sandstone interbeds are commonly sharp based, with small-scale basal scours, and are normally graded (fig. 13). Sandstones include volcaniclastic arenites and quartzo-feldspathic lithic arenites with abundant plagioclase feldspar, quartz, and chert and lime mud-wackestone lithics (fig. 14). Thickening and coarsening upward packages are most commonly made up of thin-bedded argillaceous or silty mudstone or calcareous siltstone and medium-bedded lime mud/ wackestone (fig. 13).

The siliceous limestone unit represents the upper portion of the Upper Triassic Kamishak Formation and is interbedded with contorted and faulted limestones (Wang and others, 1988; Detterman and others, 1996) that appear to be similar lithologically. Where siliceous limestones are interbedded with silty mud/wackestone or calcareous siltstone the unit resembles the rhythmically bedded unit; however, thick successions of homogenous siliceous limestone and thin interbedded sandstones set this unit apart.

\section{ICHNOLOGY}

Trace fossils are very abundant and diverse in the siliceous limestone unit (table 2). Ichnofossils were not readily apparent in the other units of the Kamishak Formation although the texture of the nodular limestones could have been influenced by bioturbation (Tucker and Wright, 1990; Flügel, 2004).

Figure 15. Outcrop photographs of trace fossils and bioturbation in the siliceous limestone unit. A. Two truncation/colonization (dashed and dotted lines) surfaces are apparent in this photo. Below the first surface (dashed line) is a suite of Rosellia socialis developed in a light gray wackestone. These suspension-feeder trace fossils indicate fully marine, typically lower shoreface to offshore transition conditions. Re-burrowing of a Rosellia mud ball, by Palaeophycus and Planolites (or possibly Chondrites) is evident within the dashed polygon. Above the truncation surface are two graded beds. The first comprises laminated fine-grained sediments that are relatively unbioturbated with a mudstone at the top colonized by a low-density Planolites community. A Chondrites-Cylindrichnus suite with a distinctive light-grey infill more extensively colonizes the second graded bed. These are both deposit feeding traces and indicate a lack of food delivered in suspension thus a deeper environment (for example, distal offshore or deeper). A Thalassinoides suite with a distinctive yellow-grey infill overprints this suite. Thalassinoides burrow walls are sharp, suggesting they were developed in a firm substrate. Based on color, the burrow-fill of the Chondrites-Cylindrichnus suite appear genetically linked to the sediments above the second truncation surface and suggest post-truncation colonization of this bedding surface. The Thalassinoides infill suggests later colonization and may indicate a lacuna (Glossifungites) surface above. B. This photo documents three similar cycles that coarsen upward from a thin darker-colored mudstone to thicker-bedded lighter-colored wackestone. All three cycles display similar colonization patterns dominated by suspension-feeding organisms (such as Cylindrichnus, Anchonichnus) but the basal mudstones likely represent lower sedimentation rates and are colonized by a higher degree of deposit-feeding organisms. C. This bedding surface illustrates extensive colonization by an organism forming mud-lined burrows. Superficially, these burrows appear to belong to Thalassinoides, however lack of continuity, funnel shapes instead of Y-branches and concentric fill in some burrows (see arrow Rot) suggest these belong to Rosellia, although these specimens appear to be oriented oblique to bedding rather than vertical, which is typical for Rosellia. D. Photograph illustrates a Zoophycos-like burrow that deviates from the archetype in that it does not appear to revolve around a central shaft. It instead forms a series of branching lobes that, in isolation, exhibit morphology approaching that of Rhizocorallium. Definitive identification would require a more complete specimen. From close inspection an open outer tube is visible on the side of one of the lobes (arrow), indicating a J-shaped, causative burrow in the sense of Wetzel and Werner (1980); this indicates relatively well oxygenated conditions. E. Photograph illustrates Planolites isp. The burrow density appears highest within muddy facies and suggests exploitation of this as a food resource. Some of these burrows show branching and are transitional to a Chondrites-like form. F. The main burrow illustrated is Chondrites, likely formed by a single organism. Note the circular and mud-filled burrows suggesting an open burrow system filled from above. Close inspection reveals sediments were previously bioturbated by Palaeophycus. G. This incomplete specimen is likely Rhizocorallium, a causative burrow that is best developed along the top edge. Spreitenate fill is visible throughout. This may be part of a multi-lobed structure similar to that illustrated in D. H. Photograph illustrates a bedding plane similar to that in C. Many of the burrows appear to be Rosellia rotatus. The large, linear burrow in the center of the photograph is either Thalassinoides or Planolites. 


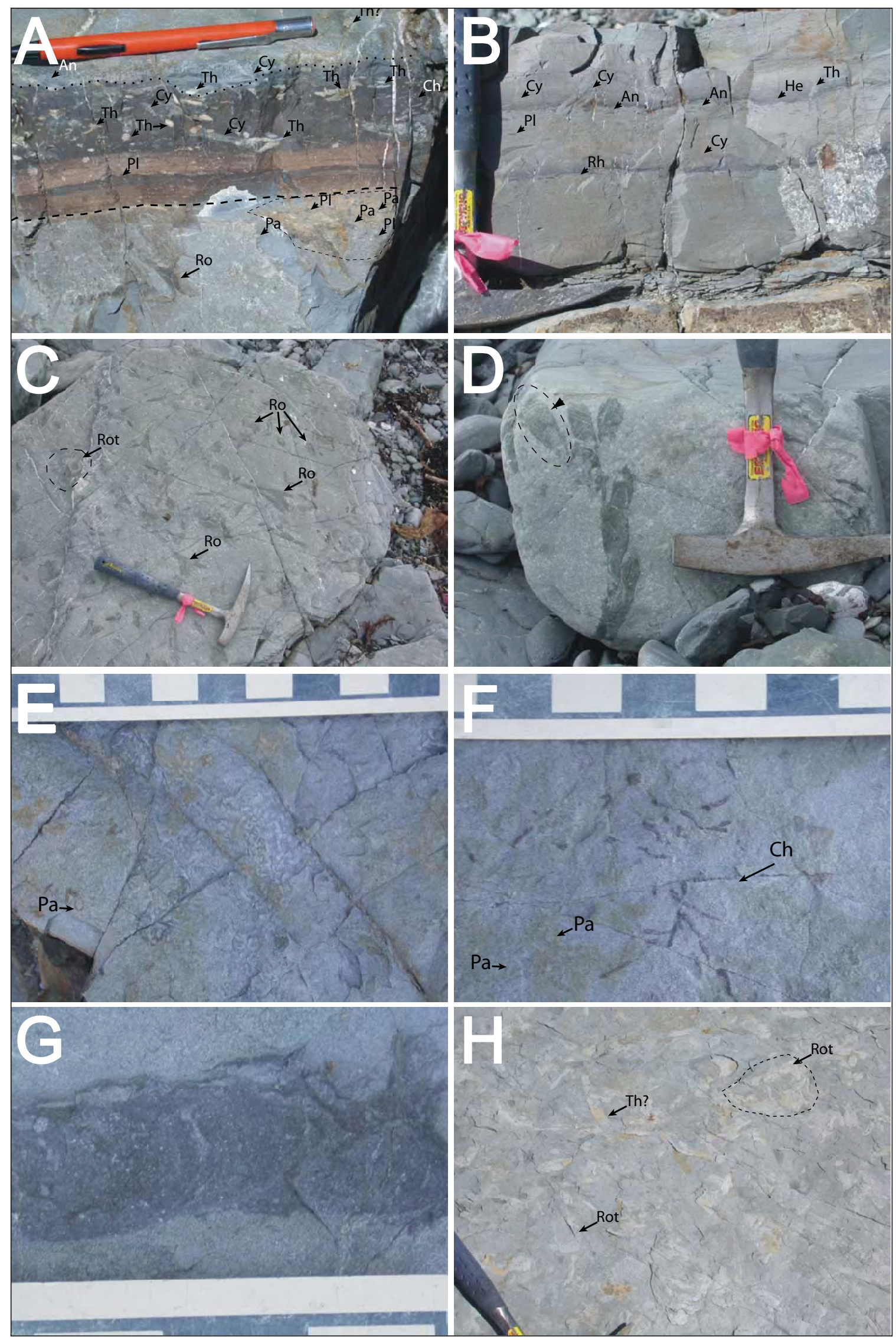


Thin to medium beds of light gray mud/wackestones in the siliceous limestone unit display two different common ichnofaunal associations. One consists mainly of Rosellia rotatus, Rosellia socialis, and Thalassinoides isp.; Planolites, Palaeophycus, Cylindrichnus, and Chondrites dominate another (table 2; fig. 15). There are examples of superposition of ichnocoenese or multiple colonization events with traces like Rosellia socialis reburrowed by Palaeophycus and Planolites, and Chondrites and Cylindrichnus overprinted by Thalassinoides (table 2; fig. 15). These patterns are likely controlled by variations in the type of substrate, rates of sedimentation including delivery of suspended organic matter, and redox conditions. Traces such as Rosellia socialis and those resembling Zoophycos or Rhizocorallium are indicative of well-oxygenated conditions while Chondrites is commonly interpreted to indicate a dysoxic environment (table 2; fig. 15). Associations of Chondrites-Cylindrichnus are mainly deposit feeding traces indicating relatively distal offshore environments while those like Rosellia socialis were produced by suspension feeders near the shoreface to offshore transition.

\section{DEPOSITIONAL INTERPRETATIONS BIOSTROMAL UNIT}

While some of the biostromal unit can accurately be classified as a packed biomicrite or wackestone (Wang and others 1988), this categorization is misleading in the sense that these facies would normally indicate deposition in relatively calm waters where carbonate mud accumulated under little influence from waves or currents. As noted by Wang and others (1988, p. 1468), the lower part of the section represents deposition in a relatively shallow water carbonate environment based on the presence of "calcareous green algae, meteoric diagenesis resulting in dissolution of aragonitic grains, lack of any pelagic components, and presence of colonial scleractinian corals with characteristics of modern shallow-water hermatypic corals" (fig. 8). The biostromal unit does not contain boundstone facies or any other evidence of rigid reefal framework. The chaotic arrangement of bioclasts including the relatively large overturned coral colonies (fig. 8C, D) indicates that this unit was deposited either in an area of some wave or

Table 2. Trace fossils identified from the siliceous limestone unit. Table lists ichnotaxa, abbreviations (see fig. 15), and descriptions of different trace fossils from the siliceous limestone unit.

\begin{tabular}{|c|c|c|}
\hline $\begin{array}{r}\text { Ichnotaxa } \\
\text { Anchonichnus isp. }\end{array}$ & $\begin{array}{l}\text { Abbreviation } \\
\text { An }\end{array}$ & $\begin{array}{l}\quad \text { Description } \\
\text { Small, smooth, irregularly meandering trails, usually with a } \\
\text { dark core surrounded by a lighter halo; not limited to bedding } \\
\text { planes }\end{array}$ \\
\hline Chondrites isp. & $\mathrm{Ch}$ & $\begin{array}{l}\text { Complex, dendritic system of regularly branching, non- } \\
\text { interpenetrating tunnels of uniform diameter. Commonly } \\
\text { interpreted as indicative of dysoxic substrate conditions }\end{array}$ \\
\hline Cylindrichnus isp. & $\mathrm{Cy}$ & $\begin{array}{l}\text { Vertical or inclined, straight or weakly curved, unbranched } \\
\text { tubes with an exterior hall of multiple concentric layers }\end{array}$ \\
\hline Palaeophycus tubularis & $\mathrm{Pa}$ & Smooth, unornamented, and thinly lined burrows \\
\hline Planolites montanus & $\mathrm{Pl}$ & $\begin{array}{l}\text { Smooth, unlined, and unbranched burrows, straight to curved. } \\
\text { Burrow fill differs in color and/or texture from the host rock }\end{array}$ \\
\hline Rosellia socialis & Ro & $\begin{array}{l}\text { Gently curved lower burrow with upper funnel-shaped opening. } \\
\text { Back-filled shaft and lower funnel. Indicative of well- } \\
\text { oxygenated, fully marine environment characteristic of the } \\
\text { proximal Cruziana ichnofacies (Eckdale and others, 1984) }\end{array}$ \\
\hline Rosellia rotatus & Rot & $\begin{array}{l}\text { Vertical or inclined, straight or curved cylindrical tube that is } \\
\text { enlarged to a funnel shape in upper parts; the funnel comprises } \\
\text { finer-grained sediment with intensively developed, crescentric } \\
\text { backfill structures formed by rotary movements of the tube } \\
\text { within the funnel }\end{array}$ \\
\hline Thalassinoides isp. & Th & $\begin{array}{l}\text { Cylindrical burrows forming three-dimensional branching } \\
\text { systems comprising horizontal networks connected to the } \\
\text { surface by vertical shafts. }\end{array}$ \\
\hline cf. Zoophycos & Zo & Spreitenate burrow \\
\hline
\end{tabular}


current agitation or possibly on the slope. The abundant shallow water fauna argues against a slope environment but deposition on a storm-influenced middle to outer carbonate ramp could explain the juxtaposition of muddy facies and transported bioclasts.

Wang and others (1988) document dissolved aragonitic grains and Sralla and Blodgett (2007) observed coarsely crystalline dolostones and collapse breccias in the lower portion of the biostromal unit that they attributed to an episode of subaerial exposure and meteoric diagenesis prior to deposition of the upper portion of the unit. Unfortunately, the lower $35 \mathrm{~m}$ of this unit were inaccessible due to high tide while we were conducting our fieldwork at this locality and we were unable to examine that part of the section. It should be noted that more recent research indicates that submarine dissolution of aragonitic grains is much more common than previously believed (Melim and others, 1995; 2002) and it would be worth re-examining the lower portion of the biostromal unit in this light.

\section{NODULAR LIMESTONE AND CAR- BONATE CONGLOMERATE}

The nodular limestone and carbonate conglomerate unit is entirely equivalent to the carbonate conglomerate of Wang and others (1988) and Detterman and others (1996). The lower part of this unit is conglomeratic as described above. However, the complex underlying deformed package indicates that the conglomerate was most likely produced by synsedimentary deformation and soft sediment folding that caused mass movement of partially lithified nodules (fig. 11). The inclusion of greenish volcanic clasts within the deformed interval implies that greenish volcanic breccias were locally exposed to erosion and redeposition during deposition of the lowermost nodular limestone and carbonate conglomerate unit. The unit becomes less conglomeratic upsection at 07MW005 and displays a nodular texture (fig. 11). At section 07MW007, nodular facies are interbedded at $\mathrm{m}$-scale with carbonate rudstones and floatstones with abundant lithoclasts and bioclasts (figs. 5, 9).

Nodular textures are in part produced by patchy submarine cementation and burrowing, followed by differential compaction, transport and redeposition of partly cemented limestones, or shear processes affecting limestone-shale alternations (Tucker and Wright, 1990; Flügel, 2004). Nodules commonly develop during early diagenesis via anaerobic, bacterial catabolysis of organic matter that results in carbonate cementation (Gluyas, 1984). Other researchers cite the influence of pressure solution on the final form of the nodules (Möller and Kvingan, 1988). Nodular facies are quite common in carbonate slope and outer carbonate ramp environments including examples in the Ordovician, Silurian (Gluyas, 1984; Möller and Kvingan, 1988), Devonian (Whalen and others, 2000), Carboniferous (Gluyas, 1984; Dumoulin and others, 2008), and Jurassic (Gluyas, 1984). A carbonate slope interpretation is also supported by the deformation that likely resulted from gravitational mass movement during deposition and loading of the overlying nodular limestone. The indication of slope deposition in the nodular limestone unit implies that the Kamishak carbonate ramp was distally steepened, at least during deposition of the lower part of the succession.

\section{RHYTHMICALLY BEDDED UNIT}

The laminated and thin-bedded character (fig. 12) and the lack of any sedimentary structures indicative of wave or current energy indicate that the rhythmically bedded unit was deposited in a relatively quiet water setting below storm wavebase. This interpretation is supported by the presence of abundant, well-preserved, thin-shelled Monotid bivalves (fig. 12C). On the basis of its stratigraphic position above the nodular limestone unit, it would appear that this unit was deposited in more seaward slope or basinal environments. The rhythmically bedded unit records progressive deepening over the slope environment indicated by the underlying nodular limestone.

The greenish volcanic breccia unit is clearly interbedded with the rhythmically bedded unit near the mouth of Puale Bay (Wang and others, 1988; Detterman and others, 1996). The stratigraphic relationships to the east, near Cape Kekurnoi, are less clear but the volcanic breccias outcrop below Monotis-bearing limestones that are clearly Upper Triassic in age although locally the contact is faulted (Hall, 1979; this study; fig. 11D) or an angular unconformity (Hanson, 1957; Hall, 1979; Blodgett and Sralla, 2008).

Hall (1979), Wang and others (1988), and Detterman and others (1996) considered the volcaniclastic rocks to be Triassic in age, and interbedded with limestones of the Kamishak Formation. Hanson (1957) inferred that they are Permian in age, underlying an angular unconformity with the Triassic limestones, an interpretation adopted by Blodgett and Sralla (2008). Greenish clasts within various Kamishak Formation units imply that these volcaniclastic breccias were, at least in part, exposed throughout deposition of much of the Kamishak.

These rocks were equated with the Shuyak Formation on Kodiak Island where Upper Triassic fossils were reported (Burk, 1965; Moore, 1967; Hill, 1979). Alternatively they were interpreted to be equivalent to the Triassic Cottonwood Bay Greenstone but no direct evidence for this age, from the Puale Bay area, was cited (Detterman and Reed, 1980; Detterman and others, 1996; Wilson and others, 1999). The Permian age is based on 
middle Permian fossils, identified by Jeffords in Hanson (1957), from a limestone on a small island approximately $5.5 \mathrm{~km}$ to the southwest of the rocks exposed on the mainland near Cape Kekurnoi. The stratigraphic context of the limestone is uncertain. Nowhere is the Permian limestone observed as interbedded with the volcanics and there is no direct evidence of age cited from the volcaniclastic or volcanic rocks themselves (Hanson, 1957; Blodgett and Sralla, 2008). Hill (1979) draws a distinction between the volcaniclastic rocks on the islands that contain reddish andesitic clasts from those on the mainland that are dominated by greenish basaltic clasts. The age of these volcaniclastic rocks thus remains in question although Blodgett and Sralla (2008) and Blodgett (this volume) concur with Hanson's (1957) Permian age assignment and Decker (this volume, figs. 3 and 4) tentatively depicts the volcaniclastic rocks as probably Permian in age. Based on the stratigraphic relationships observed during this study and previously published work the more parsimonious interpretation seems to be that these volcaniclastic rocks are Upper Triassic in age and interbedded with the Kamishak Formation (Hill, 1979; Wang and others, 1988; Detterman and others, 1996).

\section{SILICEOUS LIMESTONE UNIT}

The siliceous limestone unit displays wavy bedding surfaces and potentially hummocky cross stratification (HCS) that would indicate deposition under the influence of storm waves. The scours and normal grading of packstone to mudstone packages and some of the interbedded sandstones (figs. 13, 14) indicates unidirectional traction transport in a waning current. The lack of other abundant sedimentary structures implies that this unit was largely deposited below fairweather wave base. The graded beds and HCS are likely storm deposits and the depositional setting would have been above storm wave base in a lower shoreface to offshore or outer carbonate ramp environment. This interpretation is supported by ichnofossils, such as Rosellia socialis, which are commonly interpreted as indicators of similar environments (fig. 15). Sedimentologic and ichnofauna indicate that the unit fluctuates between somewhat deeper offshore and shallower lower shoreface settings recorded in numerous thickening and coarsening upward cycles. The sedimentologic and ichnofabric data imply that the siliceous limestone unit records a general shoaling compared to the slope and possibly basinal units in the underlying nodular limestone and conglomerate and rhythmically bedded units. The interbedded sandstones with plagioclase and greenish volcanic lithic grains indicate that greenish volcanic breccias were locally exposed to erosion and redeposition during deposition of the siliceous limestone unit. This unit makes up the bulk of the Kamishak Formation and more detailed stratigraphic data throughout the unit will be necessary to better define its overall depositional history.

\section{REGIONAL PALEOGEOGRAPHY}

The facies of the Kamishak Formation record deposition on a carbonate ramp in middle to outer ramp and ramp slope/basin environments. The biostromal unit is interpreted as a middle to outer ramp deposit, the nodular limestone and conglomerate unit as upper slope facies, the rhythmically bedded unit as slope or basin deposits, and the siliceous limestone as indicating an outer carbonate ramp environment. The presence of slope-deposited units indicates that the carbonate ramp was distally steepened at least through deposition of the nodular limestone and conglomerate unit. It is unclear whether this distally steepened profile remained during deposition of the rhythmically bedded and siliceous limestone units.

The basal depositional contact of the Kamishak Formation is not exposed where the lowermost Kamishak crops out (locality 07MW005). The exposure documented at locality 07MW001 records the onlap of the Kamishak onto an erosional surface atop the volcaniclastic rocks. Lithologically these onlapping Kamishak facies appear similar to the siliceous limestone unit. Thin greenish sandstone beds are found in the Kamishak exposed above the underlying greenstone at 07MW001 and similar sandstones were documented in section 07MW003 and 4 and greenish clasts were noted in the deformed unit at the base of the nodular conglomerate in section 07MW005. This would indicate that the underlying volcaniclastic unit formed a topographic high that was at least partly exposed to subaerial or submarine erosion during deposition of much of the Kamishak. Units overlying the biostromal unit all indicate deeper water environments indicating active subsidence and/or relative sea level rise. However, the underlying volcaniclastics served a local source of greenish sand and clasts through deposition of the siliceous limestone unit. This implies that the volcanic/volcaniclastic edifice remained partially emergent or was locally uplifted during deposition of the Kamishak. The common fault contact of the Kamishak with the underlying volcaniclastics and the deformed unit between the biostromal and nodular limestone and conglomerate units supports the interpretation that the rocks were undergoing active Upper Triassic synsedimentary tectonic deformation.

\section{SOURCE ROCK POTENTIAL}

Organic geochemical analyses conducted included total organic carbon (TOC) and Rock-Eval pyrolysis. TOC is the sum of the total kerogen (insoluble, disseminated organic matter) and bitumen (soluble, disseminated organic matter) in a rock (Waples, 1981) and the con- 
centration is directly related to source-rock quality. Rock-Eval is a method used to determine the types of kerogen and the quality of the organic matter that relate to the source rock potential (Peters, 1986). Rock-Eval analyses measure several parameters other than TOC: $\mathrm{S} 1, \mathrm{~S} 2$, and $\mathrm{S} 3$ are parameters measured with respect to values obtained from one gram of rock. S1 indicates milligrams of hydrocarbons that can be thermally distilled; $\mathrm{S} 2$ represents milligrams of hydrocarbons generated by pyrolytic degradation of kerogen; and S3 indicates milligrams of CO2 generated during pyrolysis (Peters, 1986). Tmax is the temperature at which the greatest amounts of S2 hydrocarbons are generated. Potential petroleum source rocks will have at least 0.5 percent TOC and very good source rocks are characterized by $>2$ percent (Peters, 1986). Peters (1986) and Espitalié and others (1985) also use the S2 value to gain insight into source rock potential with values of 5 to $10 \mathrm{mg}$ hydrocarbon $/ \mathrm{g}$ rock indicating good to very good potential. Tmax and the production index (PI) can be used to estimate thermal maturity, with Tmax and PI values less than 435C and 0.1 respectively, indicating immature rocks (Peters, 1986). Espitalié and others (1977) pioneered the use of Rock-Eval data to evaluate types of kerogen similar to atomic $\mathrm{H} / \mathrm{C}$ vs. $\mathrm{O} / \mathrm{C}$ diagrams. They defined and cross plotted the hydrogen index $(\mathrm{HI}=[\mathrm{S} 2 / \mathrm{TOC}] \times 100)$ and oxygen index $(\mathrm{OI}=[\mathrm{S} 3 / \mathrm{TOC}] \times 100$ to describe the types of organic matter within samples.

The following summarizes the organic geochemical data for Kamishak Formation samples. For a more detailed analysis of the organic geochemistry of Kamishak and other Bristol Bay samples see Decker (this report). The mean TOC value of all Kamishak Formation samples collected was 1.52 percent with a high of 5.28 percent (table 3). Eighteen of 31 Kamishak samples had TOC values $>1.0$ percent, indicating that many of the lithofacies are potential source rocks; only 10 samples had $>2$ percent TOC, indicating very good source potential (table 3). The best source rocks appear to be within the rhythmically bedded and siliceous limestone units (table 3). The mean S2 for all Kamishak samples is $8.41 \mathrm{mg} \mathrm{HC} / \mathrm{g}$ with a range of 0.05 to 39.87 , indicating a wide range of source potential (table 3 ). Tmax measurements from samples with $\mathrm{S} 2$ values of $<0.2 \mathrm{mg} \mathrm{HC} / \mathrm{g}$ are often inaccurate (Peters, 1986) and were omitted when calculating the average Tmax of $434^{\circ} \mathrm{C}$ for Kamishak samples (table 3 ). Mature source rocks generally have Tmax values between 435 and $470^{\circ} \mathrm{C}$ (Peters, 1986) so the Kamishak appears to be near the boundary of immature and mature source rocks. This is supported by the relatively low PI values, averaging 0.09 . Values derived from Rock-Eval can be affected by the types of included organic matter or rock-matrix adsorption of hydrocarbons liberated by pyrolysis and should be verified by other methods such as vitrinite reflectance or gas chromatography (Katz, 1983; Espitalié and others, 1985; Peters, 1986; Langford and Blanc-Valleron, 1990). HI values range from 8 to 785 (mean 380) and OI values range from 8 to 806 (mean of 108). Kamishak Formation samples display a wide distribution on a van Krevelen diagram, indicating that kerogen ranges from Type 1 (very oil prone) to Type III (gas prone) (fig. 16). Average values plot as Type II (oil prone) kerogen. These data support previous organic geochemical analyses reported in Wang and others (1988).

\section{RESERVOIR POTENTIAL}

Very few of the facies examined during this study contain any significant porosity that would indicate reservoir rock potential. The only facies that appear to have some macroscale porosity occur within the conglomerates (rudstones and floatstones) of the nodular limestone and conglomerate unit. At section 07MW007, centimeter-scale vugs occur within a rudstone bed near the base section and millimeter-scale vugs were documented in a rudstone unit several meters above (fig. 9). This indicates meter-scale units with some reservoir potential but the lateral extent of these units was not documented. At the microscopic scale there is almost no observable primary and very minor secondary porosity in the form of unfilled fractures (fig. 10A) and small dissolution vugs associated with pyrite diagenesis (fig. 10F). Dolomite observed in the biostromal unit was relatively fine crystalline replacement dolomite and was not associated with secondary porosity. Some fractures within the biostromal unit appeared open in outcrop but all fractures observed in thin section were filled with calcite. More detailed analyses would be necessary to determine the timing and mode of dolomitization in these rocks. Sralla and Blodgett (2007) report porous sucrosic dolomite from lower levels within the biostromal unit near section 07MW007 and from subsurface wells but that texture was not observed in outcrop samples or thin sections examined for this study. While this outcrop analysis does not point to very good reservoir potential, subsurface data from the Kamishak Formation indicates significant permeability (average 15.5 millidarcies), and reservoir quality rocks in the nearby subsurface (Sralla and Blodgett, 2007; Blodgett and Sralla, 2008).

\section{CONCLUSIONS}

The Upper Triassic portion of the Kamishak Formation was examined for this study to lend insight into the lithofacies, stratigraphy, depositional environments, and source and reservoir rock potential. Four partial stratigraphic sections were measured and samples were collected for thin section, TOC, Rock-Eval pyrolysis, and/or reservoir seal analyses. Stratigraphic and petrographic analyses identified four lithostratigraphic units 
including a biostromal, nodular limestone and conglomerate, rhythmically bedded, and siliceous limestone unit. Bedding characteristics, sedimentary structures, and trace fossils indicate that the biostromal unit was deposited on a middle to outer carbonate ramp possibly above fair weather wave base. The nodular limestone and carbonate conglomerate was, as Wang and others (1988) interpreted, likely deposited on a distally steepened slope of the carbonate ramp. The folded unit, identified at the base of the nodular limestone and conglomerate, implies that the overlying carbonate conglomerate was formed through synsedimentary deformation and downslope movement. The rhythmically bedded unit displays no evidence of wave or current transport and implies deposition below storm wave base, likely in a deep slope or basin environment. The overlying siliceous limestone unit records a general shoaling and deposition in relatively deep offshore to offshore-shoreface transition environments on an outer carbonate ramp. Trace fossil assemblages in the siliceous limestone support this interpretation.

The base of the Kamishak Formation is commonly a fault contact (Wang and others, 1988; Detterman and others, 1996) but locally the unit appears to onlap an angular unconformity atop the underlying greenish volcaniclastic unit (Hanson, 1957; Blodgett and Sralla,

Table 3. Organic geochemical data for Kamishak Formation samples.

\begin{tabular}{|c|c|c|c|c|c|c|c|c|c|c|}
\hline \multirow[b]{2}{*}{ Latitude } & \multirow[b]{2}{*}{ Longitude } & \multirow{2}{*}{$\begin{array}{c}\text { TOC } \\
\text { Wt. } \\
\% \\
\end{array}$} & \multirow{2}{*}{$\begin{array}{c}\mathrm{S} 1 \\
\mathrm{mg} / \mathrm{g}\end{array}$} & \multirow{2}{*}{$\begin{array}{c}\mathrm{S} 2 \\
\mathrm{mg} / \mathrm{g}\end{array}$} & \multirow{2}{*}{$\frac{\mathrm{S} 3}{\mathrm{mg} / \mathrm{g}}$} & \multirow[b]{2}{*}{ Tmax } & \multirow[b]{2}{*}{ HI } & \multirow{2}{*}{ OI } & \multirow{2}{*}{$\begin{array}{c}\text { S1/ } \\
\text { TOC }\end{array}$} & \multirow[b]{2}{*}{ PI } \\
\hline & & & & & & & & & & \\
\hline 57.71453 & -155.36455 & 1.85 & 1.04 & 9.60 & 0.48 & 435 & 519 & 26 & 56 & 0.10 \\
\hline 57.71367 & -155.362 & 0.07 & 0.04 & 0.17 & 0.27 & 439 & 250 & 395 & 56 & 0.18 \\
\hline 57.71445 & -155.36302 & 0.60 & 0.16 & 1.23 & 0.34 & 433 & 206 & 57 & 27 & 0.11 \\
\hline 57.71844 & -155.39035 & 3.40 & 1.97 & 26.69 & 0.39 & 434 & 785 & 11 & 58 & 0.07 \\
\hline 57.71819 & -155.39078 & 2.95 & 1.72 & 22.05 & 0.42 & 434 & 746 & 14 & 58 & 0.07 \\
\hline 57.71493 & -155.36719 & 2.51 & 1.36 & 15.33 & 0.46 & 436 & 611 & 18 & 54 & 0.08 \\
\hline 57.71493 & -155.36719 & 2.53 & 1.60 & 15.27 & 0.46 & 433 & 604 & 18 & 63 & 0.09 \\
\hline 57.71499 & -155.36575 & 1.20 & 0.34 & 5.41 & 0.29 & 434 & 450 & 24 & 28 & 0.06 \\
\hline 57.71367 & -155.362 & 0.09 & 0.02 & 0.18 & 0.25 & 442 & 207 & 285 & 22 & 0.10 \\
\hline 57.7137 & -155.36179 & 0.10 & 0.01 & 0.05 & 0.22 & 469 & 50 & 221 & 10 & 0.16 \\
\hline 57.72574 & -155.33485 & 2.41 & 0.73 & 8.12 & 0.37 & 436 & 337 & 15 & 30 & 0.08 \\
\hline 57.72586 & -155.3353 & 2.98 & 0.93 & 21.22 & 0.32 & 435 & 713 & 11 & 31 & 0.04 \\
\hline 57.72554 & -155.33755 & 5.28 & 3.23 & 39.87 & 0.41 & 440 & 756 & 8 & 61 & 0.07 \\
\hline 57.72556 & -155.33821 & 4.83 & 2.10 & 36.55 & 0.51 & 436 & 756 & 11 & 43 & 0.05 \\
\hline 57.72556 & -155.33821 & 1.74 & 0.76 & 12.54 & 0.48 & 439 & 720 & 27 & 43 & 0.06 \\
\hline 57.71477 & -155.36534 & 2.13 & 1.07 & 12.55 & 0.40 & 435 & 589 & 19 & 50 & 0.08 \\
\hline 57.71412 & -155.36342 & 0.44 & 0.12 & 0.78 & 0.27 & 429 & 176 & 61 & 26 & 0.13 \\
\hline 57.72483 & -155.34138 & 0.04 & 0.01 & 0.08 & 0.29 & 460 & 222 & 806 & 27 & 0.11 \\
\hline 57.72523 & -155.342 & 0.43 & 0.10 & 0.85 & 0.50 & 432 & 196 & 115 & 24 & 0.11 \\
\hline 57.72499 & -155.34346 & 1.20 & 0.54 & 3.98 & 0.22 & 431 & 331 & 18 & 45 & 0.12 \\
\hline 57.72488 & -155.34433 & 2.06 & 0.56 & 7.25 & 0.69 & 430 & 352 & 33 & 27 & 0.07 \\
\hline 57.7201 & -155.38948 & 1.32 & 0.32 & 5.62 & 0.26 & 433 & 425 & 20 & 24 & 0.05 \\
\hline 57.7201 & -155.38948 & 0.62 & 0.17 & 1.79 & 0.27 & 436 & 290 & 44 & 27 & 0.09 \\
\hline 57.7201 & -155.38948 & 1.81 & 0.20 & 3.64 & 0.18 & 433 & 201 & 10 & 11 & 0.05 \\
\hline 57.7201 & -155.38948 & 1.08 & 0.18 & 3.39 & 0.22 & 434 & 314 & 20 & 16 & 0.05 \\
\hline 57.7201 & -155.38948 & 0.12 & 0.01 & 0.09 & 0.29 & 433 & 76 & 244 & 8 & 0.10 \\
\hline 57.7201 & -155.38948 & 0.26 & 0.02 & 0.32 & 0.29 & 431 & 125 & 113 & 8 & 0.06 \\
\hline 57.7201 & -155.38948 & 0.14 & 0.01 & 0.11 & 0.22 & 425 & 77 & 154 & 7 & 0.08 \\
\hline 57.7201 & -155.38948 & 1.22 & 0.33 & 5.34 & 0.26 & 432 & 437 & 21 & 27 & 0.06 \\
\hline 57.7201 & -155.38948 & 0.29 & 0.07 & 0.43 & 0.24 & 433 & 150 & 84 & 23 & 0.14 \\
\hline 57.725511 & -155.34152 & 0.07 & 0.02 & 0.07 & 0.33 & 435 & 97 & 458 & 27 & 0.22 \\
\hline
\end{tabular}




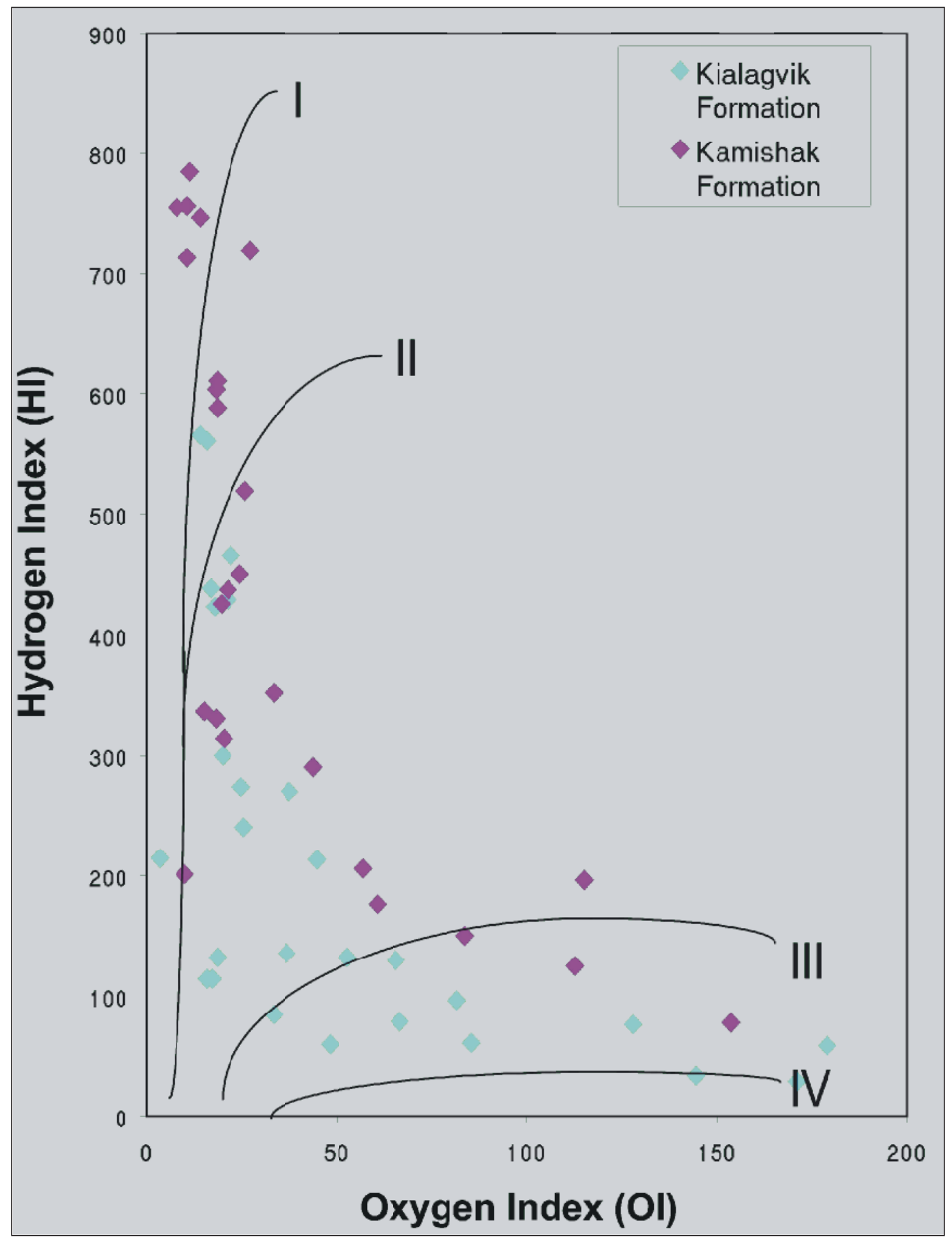

Figure 16. Modified Van Krevelen diagram based on analyses of Kamishak and Kialagvik formation samples. Note the wide range of Kamishak values ranging from Type I (very oil prone) to Type III (gas prone) kerogen. Average Kamishak values fall within Type II (oil prone) kerogen. Diagram courtesy of A. Loveland. See Decker (this report) for more detailed information on source rock analysis. 
2008). Greenish clasts identified in the deformed interval at the base of the nodular limestone and conglomerate unit and greenish sands within the siliceous limestone unit indicate that the volcaniclastics were locally exposed to erosion during deposition of much of the Kamishak Formation. This, along with the synsedimentary folds within the nodular limestone and conglomerate unit (fig. 11) and several deformed limestones in the upper Kamishak (fig. 2), implies that the area was undergoing active tectonic deformation during deposition of the Kamishak Formation.

TOC and Rock-Eval pyrolysis data indicate that some facies in the Kamishak Formation are potential source rocks that are immature to barely mature. Hydrogen Index and Oxygen Index data from kerogen in the Kamishak Formation indicates that it is both oil and gas prone (fig. 16). Very few facies contain the requisite porosity to serve as potential reservoir rocks although some rudstone beds within the nodular limestone and conglomerate unit contain macroscopic secondary porosity. Overall the reservoir potential is poor.

\section{REFERENCES CITED}

Blodgett, R.B., this volume.

Blodgett, R.B., and Sralla, Bryan, 2008, A major unconformity between Permian and Triassic strata at Cape Kekurnoi, Alaska Peninsula; Old and new observations on stratigraphy and hydrocarbon potential, in Haeussler, P.J., and Galloway, J.P., eds., Studies by the U.S. Geological Survey in Alaska, 2006: U.S. Geological Survey Professional Paper 1739-E, 13 p. [http://pubs.usgs.gov/pp/pp1739/e/].

Burk, C.A., 1965, Geology of the Alaska PeninsulaIsland Arc and Continental Margin: The Geological Society of America Memoir 99, 250 p., 3 sheets.

Decker, P.L., this volume.

Detterman, R.L., and Reed, B.L., 1980, Stratigraphy, structure, and economic geology of the Iliamna Quadrangle, Alaska: U.S. Geological Survey Bulletin 1368-B, 86 p., 1 plate, scale 1:250,000.

Detterman, R.L., Case, J.E., Miller, J.W., Wilson, F.H., and Yount, M.E., 1996, Stratigraphic framework of the Alaska Peninsula: U.S. Geological Survey Bulletin 1969-A, 74 p.

Dumoulin, J.A., Whalen, M.T., and Harris, A.G., 2008, Lithofacies, age, and sequence stratigraphy of the Carboniferous Lisburne Group in the Skimo Creek area, central Brooks Range, in Haeussler, Peter J., and Galloway, John P., eds., Studies by the U.S. Geological Survey in Alaska, 2006: U.S. Geological Survey Professional Paper 1739-B, 64 p. [http://pubs. usgs.gov/pp/pp1739/b/].

Dunham, R.J., 1962, Classification of carbonate rocks according to texture, in Ham, W.E., ed., Classifica- tion of carbonate rocks: American Association of Petroleum Geologists Memoir 1, p. 108-121.

Eckdale, A.A., Bromley, R.G., and Pemberton, S.G., 1984, Ichnology trace fossils in sedimentology and stratigraphy: Society of Economic Paleontologists and Mineralogists Short Course 15, $317 \mathrm{p}$.

Embry, A.F., and Klovan, J.E., 1972, Absolute water depth limits of late Devonian paleoecological zones: Geological Research, v. 61, p. 672-686.

Espitalié, J., Deroo, G., and Marquis, F., 1985, La pyrolyse Rock-Eval et ses applications: Revue de 1'Institut Français du Pétrole, v. 40, p. 563-579 and 755-784.

Espitalié, J., Madec, M., and Tissot, B., 1977, Source rock characterization method for petroleum exploration: Proceedings of the 9th Annual Offshore Technology Conference, v. 3, p. 439-448.

Flügel, E., 2004, Microfacies of carbonate rocks; Analysis, interpretation, and application: BerlinHeidelberg, Springer-Verlag, 976 p.

Gluyas, J.G., 1984, Early carbonate diagenesis within Phanerozoic shales and sandstones of the northwest European shelf: Clay Minerals, v. 19, p. 309-321.

Hanson, B.M., 1957, Middle Permian limestone on Pacific side of Alaska Peninsula: American Association of Petroleum Geologists Bulletin, v. 41, no. 10, p. 2,376-2,378.

Hill, M.D., 1979, Volcanic and plutonic rocks of the Kodiak-Shumagin shelf, Alaska; Subduction deposits and near-trench magmatism: Santa Cruz, CA, University of California Santa Cruz, Ph.D. Dissertation, $259 \mathrm{p}$.

Imlay, R.W., 1981, Early Jurassic ammonites from Alaska: U.S. Geological Survey Professional Paper 1190,40 p.

Imlay, R.W., and Detterman, R.L., 1977, Some Lower and Middle Jurassic beds in Puale Bay-Alinchak Bay area, Alaska Peninsula: Bulletin of the American Association of Petroleum Geologists, v. 61, no. 4, p. 607-611.

Katz, B.J., 1983, Limitations of 'Rock-Eval' pyrolysis for typing organic matter: Organic Geochemistry, v. 4, p. 195-199.

Langford, F.F., and Blanc-Valleron, M.-M., 1990, Interpreting Rock-Eval pyrolysis data using graphs of pyrolizable hydrocarbons vs. total organic carbon: American Association of Petroleum Geologists Bulletin, v. 74, p. 799-804.

Melim, L.A., Swart, P.K., and Maliva, R.G., 1995, Meteoric like fabrics forming in marine waters; Implications for the use of petrography to identify diagenetic environments: Geology, v. 23, p. 755-758.

Melim, L.A., Westphal, H., Swart, P.K., Eberli, G.P., and Munnecke, A., 2002, Questioning carbonate diage- 
netic paradigms; Evidence from the Neogene of the Bahamas: Marine Geology, v. 185, p. 24-54.

Möller, N.K., and Kvingan, K., 1988, The genesis of nodular limestones in the Ordovician and Silurian of the Oslo Region (Norway): Sedimentology, v. 35, p. 405-420.

Moore, G.W., 1967, Preliminary geologic map of the Kodiak Islands and vicinity: U.S. Geological Survey Open File Report 271, 1 plate, scale 1:250,000.

Newton, C.R., 1983, Paleozoogeographic affinities of Norian bivalves from the Wrangellian, Peninsular, and Alexander terranes, northwestern North America, in Stevens, C.H., ed., Pre-Jurassic rocks in western North American suspect terranes: Society of Economic Paleontologists and Mineralogists Symposium, Sacramento, CA, 1983, p. 37-48.

Newton, C.R., 1989, Triassic-Jurassic boundary section at Puale Bay, Alaska Peninsula; Comparative diversity patterns of skeletal faunas and trace fossils: American Association of Petroleum Geologists Bulletin, v. 74, p. 730.

Pálfy, József, Smith, P.L., Mortensen, J.K., and Friedman, R.M., 1999, Integrated ammonite biochronology and U-Pb geochronometry from a basal Jurassic section in Alaska: Geological Society of America Bulletin, v. 111, no. 10, p. 1,537-1,549.

Peters, K.E., 1986, Guidelines for evaluating petroleum source rock using programmed pyrolysis: American Association of Petroleum Geologists Bulletin, v. 70, p. 318-329.

Sralla, Bryan, and Blodgett, R.B., 2007, Reservoir potential of Late Triassic Kamishak Formation; Puale
Bay, Alaska Peninsula [abs.]: American Association of Petroleum Geologists Annual Convention \& Exhibition, Long Beach, CA, 2007, Abstracts, v. 91 (digital), p. 132.

Tucker, M.E., and Wright, V.P., 1990, Carbonate Sedimentology: Oxford, England, Blackwell Publishing, $482 \mathrm{p}$.

Wang, Jason, Newton, C.R., and Dunne, L., 1988, Late Triassic transition from biogenic to arc sedimentation on the Peninsular terrane, Puale Bay, Alaska Peninsula: Geological Society of America Bulletin, v. 100 , no. 9 , p. $1,466-1,478$.

Waples, D., 1981, Organic geochemistry for exploration geologists: Minneapolis, Minnesota, Burgess Publishing Company, $151 \mathrm{p}$.

Wetzel, A., and Werner, F., 1980, Morphology and ecological significance of Zoophycos in deep-sea sediments off northwest Africa: Palaeogeography, Palaeoclimatology, Palaeoecology, v. 32, p. 185-212.

Whalen, M.T., Eberli, G.P., van Buchem, F.S.P., Mountjoy, E.W., and Homewood, P.W., 2000, Bypass margins, basin-restricted wedges and platform-tobasin correlation, upper Devonian, Canadian Rocky Mountains; Implications for sequence stratigraphy of carbonate platform systems: Journal of Sedimentary Research, v. 70, p. 913-936.

Wilson, F.H., Detterman, R.L., and DuBois, Gregory, 1999, Digital data for the geologic framework of the Alaska Peninsula, Southwest Alaska, and the Alaska Peninsula Terrane: U.S. Geological Survey OpenFile Report 99-317, 41 p., 1 plate, scale 1:500,000, http://wrgis.wr.usgs.gov/open-file/of99-317. 